\title{
Feeding a concentrate rich in rapeseed oil improves fatty acid composition and flavor in Norwegian goat milk
}

\author{
R. A. Inglingstad, ${ }^{* 1}$ S. Skeie, ${ }^{*}$ G. E. Vegarud, ${ }^{*}$ T. G. Devold, ${ }^{*}$ Y. Chilliard, $†$ and M. Eknæs $\ddagger$ \\ *Faculty of Chemistry, Biotechnology and Food Science (KBM), Norwegian University of Life Sciences (NMBU), 1430 Ås, Nroway \\ †UMR1213 Herbivores, Institut National de la Recherche Agronomique (INRA)-Clermont-Theix-Lyon, F-63122 Saint-Genès-Champanelle, France \\ łFaculty of Biosciences (BIOVIT), Norwegian University of Life Sciences (NMBU), 1430 Ås, Norway
}

\section{ABSTRACT}

Impaired quality due to a high content of free fatty acids (FFA) and off-flavors has caused challenges in the development of Norwegian goat milk products. The present study aimed to examine the effect of lipid-supplemented concentrates on milk fat content, fatty acid composition, FFA, lipoprotein lipase activity, sensory properties, and size of milk fat globules of goat milk. Thirty goats assigned to 3 experimental groups were fed different concentrates from $60 \mathrm{~d}$ in milk (DIM) until late lactation (230 DIM). The diets were (1) control concentrate (no added fat); (2) control concentrate with $8 \%$ (added on air-dry basis) hydrogenated palm oil enriched with palmitic acid (POFA); and (3) control concentrate with $8 \%$ (added on air-dry basis) rapeseed oil (RSO). The POFA group produced milk with the highest fat content, and fat content was positively correlated with the mean size of milk fat globules. Goats in the RSO group had a higher content of long-chain and unsaturated fatty acids, whereas milk from goats in the POFA group had a higher content of palmitic and palmitoleic acids (C16:0 and C16:1 cis). The control group produced milk with a higher content of short-, medium-, odd-, and branched-chain fatty acids compared with the 2 other groups. The content of FFA in milk was low in early and late lactation and peaked in mid lactation (90 DIM). A high content of FFA was correlated with poor sensory properties (tart/rancid flavor). The RSO group produced milk with lower content of FFA and off-flavors in mid lactation and a higher proportion of unsaturated fatty acids. Therefore, replacement of palm oil with rapeseed oil as a lipid source in dairy goat feed would be favorable.

Key words: rapeseed oil, palm oil, goat milk, fatty acid composition, free fatty acids

Received December 1, 2016.

Accepted May 15, 2017.

${ }^{1}$ Corresponding author: raaboe@nmbu.no

\section{INTRODUCTION}

Norwegian goat milk has been of variable quality in respect to both rennet coagulation properties and offflavors, which may be a problem in the production of cheese. The problem is most prominent in mid lactation, which sometimes coincides with the time when the goats are let out on mountain or rangeland pasture (Eknæs et al., 2006). The off-flavors of goat milk are correlated with the content of free fatty acids (FFA; Dønnem et al., 2011), and goats deficient in $\alpha_{\mathrm{S1}}-\mathrm{CN}$ [goats homozygous for a deletion in exon 12 of the gene encoding $\alpha_{\mathrm{S} 1}-\mathrm{CN}$, which causes low or no synthesis of this protein in their milk (E12-00)] have higher frequencies of FFA and off-flavors compared with goats not deficient in $\alpha_{\mathrm{S}_{1}} \mathrm{CN}$ [goats with no or only one deletion in exon 12 of the gene encoding $\alpha_{\mathrm{S}^{-}} \mathrm{CN}$; these goats express this protein in their milk (E12-11/E12-01); Dagnachew et al., 2011]. Free fatty acids result from the action of lipoprotein lipase (LPL), a highly potent enzyme that hydrolyses mainly triglycerides (TG) into glycerol and FFA. However, LPL does not reach its full lipolytic potential in milk because its substrate (TG) is localized in milk fat globules (MFG) surrounded by a protective membrane - the milk fat globule membrane (MFGM; Deeth, 2006). In cow milk, LPL is associated with the casein micelles. However, in goat milk it is probably associated with the MFGM (Chilliard et al., 2003). If the MFGM is damaged or broken, LPL will have immediate access to TG, resulting in excessive lipolysis. Previous studies (Eknæs et al., 2009) have shown that extra supplements of saturated fat (C16:0 and C18:0) in goat feed improves the milk flavor. Calcium salts of palm oil-derived fatty acids are largely used as dairy energy supplements (Onetti and Grummer, 2004; Rabiee et al., 2012). However, the use of palm oil is severely criticized, both from an environmental sustainability point of view (Wilcove et al., 2013) and from a consumer health perspective, because it increases milk palmitic acid, which is not recommended (Hayes et al., 1997; Shingfield et al., 2008). Hence, the search for a good substitute to palm oil in animal feed becomes increasingly important. 
Rapeseeds could be a more sustainable substitute for palm oil in the dairy feed. Oilseeds were introduced in Norway in the late 1950s; however, the land used for cultivation of oilseeds today is less than $1 \%$ of total cultivated farmland (Granlund et al., 2010). Several experiments feeding rapeseeds or rapeseed oil to dairy goats have shown positive effects on milk quality in terms of milk flavor and fatty acid composition. Activity of LPL and content of FFA were reduced (Ollier et al., 2009), which improve the sensory quality of the milk. Contents of SFA, especially C16:0, decreased, and contents of trans-C18:1 isomers, linoleic, linolenic, and conjugated linoleic acids increased (Gulati et al., 1997; Mir et al., 1999; Andrade and Schmidely, 2006; Ollier et al., 2009). The trans isomers C18:1 trans-6-9 are found in hydrogenated vegetable oils and believed to have a negative effect on human health, whereas C18:1 trans-11 and the CLA isomer C18:2 cis-9,trans-11 found in ruminant milk have neutral or health-promoting effects (Shingfield et al., 2008). We therefore hypothesize that rapeseed oil in the goats' diet will reduce the frequency of off-flavors and the content of FFA, and increase the proportion of UFA in the milk fat.

The aim of this study was thus to evaluate the effect of lipid-supplemented concentrate fed to Norwegian dairy goats on the following milk parameters: fat content, fatty acid composition, lipolysis, LPL activity, FFA, and MFG size. Two lipid sources were compared (saturated palm oil and unsaturated rapeseed oil) with a concentrate with no added fat (control feed). Milk samples from individual goats were collected throughout the lactation cycle. We also investigated and report separately milk protein composition and cheesemaking properties (Inglingstad et al., 2016) and goats' energy balance and milk production parameters (Eknæs et al., 2017) from the same experiment.

\section{MATERIALS AND METHODS}

\section{Experimental Design}

Thirty Norwegian dairy goats in second to fourth lactation, kidding in February 2011 (average kidding date: February $17 \pm 8$ d) and with average BW 2 $\mathrm{d}$ after kidding of $54.4 \pm 6.7 \mathrm{~kg}$ were fed a control diet until 60 DIM (preparatory period). The control concentrate consisted of barley, rapeseed meal (Expro 00SF, AarhusKarlshamn Sweden AB, Karlshamn, Sweden), soybean meal, beet pulp, molasses, and mineral/ vitamin premix. At $60 \mathrm{DIM}$, the goats were assigned to 3 experimental groups each of 10 goats receiving 3 types of feed. The diets were (1) control concentrate (CON), (2) control concentrate with $8 \%$ (air-dry basis) hydrogenated palm oil enriched with palmitic acid
(Akofeed Gigant 60, AarhusKarlshamn Sweden AB; POFA), and (3) control concentrate with 8\% (air-dry basis) rapeseed oil (AarhusKarlshamn Sweden AB; RSO). The treatment designations CON, POFA, and RSO are also used to describe the milk from the goats on the respective treatments. The experimental groups were balanced according to lactation number, kidding date, milk yield, and BW. Each group consisted of 7 goats heterozygous (E12-01) for the deletion in exon 12 at the $\alpha_{S 1}-\mathrm{CN}$ locus (CSN1S1), whereas 3 were homozygous (E12-00) for this deletion. From 0 to 130 DIM and from 200 to 230 DIM, the goats were stabled indoor in individual pens and received silage according to appetite (10\% refusals). From 130 to 200 DIM, the goats were grazing free-range in a mountain pasture about $1,000 \mathrm{~m}$ above sea level. The mountain pasture consisted of boggy areas with sedges (mainly Carex nigra and Carex rostrata) and drier areas with grass, herbs, and shrubs (mainly Deschampsia cespitosa, Salix spp., and Betula spp.; Eknæs et al., 2006). The goats received $0.9 \mathrm{~kg}$ of the experimental concentrate per day until the start of the mountain grazing season, and 0.7 $\mathrm{kg} / \mathrm{d}$ thereafter. The concentrate was fed individually with no refusals to the goats 3 times a day during the indoor period and twice a day during the mountain grazing period. Further details on animal feeding management and production performances are described in Eknæs et al. (2017).

\section{Feed Production and Analysis}

The experimental concentrate mixtures were produced by the Centre for Feed Technology at the Norwegian University of Life Sciences, and the fat contents and fatty acid composition of the concentrates and the silage are shown in Table 1.

Silage was harvested at the experimental farm at Ås, Norway, and consisted of grass of timothy (Phleum pratense), meadow fescue (Festuca pratensis), and red clover (Trifolium pratense). After cutting, the grass was wilted to achieve a DM content of $250 \mathrm{~g} / \mathrm{kg}$ of DM. The grass was baled using an Orkel HiQ (Orkel AS, Fannrem, Norway) roundbaler, preserved with Ensil1 (Felleskjøpet Agri SA, Lillestrøm, Norway; 4 L/t), and wrapped in 6 layers of plastic film (Trio Wrap, Trioplast AB, Sweden).

Fatty acid composition in silage and concentrate was analyzed by Vitas (Oslo, Norway). Dried and milled samples were accurately weighed $(200 \mathrm{mg})$ and transferred to soda lime tubes. Internal standard, methyl tricosanoate (Nu-Chek Prep, Waterville, $\mathrm{MN})$, and 900 $\mu \mathrm{L}$ of $3 \mathrm{~N}$ methanolic $\mathrm{HCl}$ were added, and samples were methylated for $2 \mathrm{~h}$ at $80^{\circ} \mathrm{C}$. Aliquots of $100 \mu \mathrm{L}$ of FAME were transferred to GC vials, diluted with hex- 
ane and injected $(1 \mu \mathrm{L}$, splitless $)$ on an Agilent 7890A Gas Chromatograph System with flame-ionization detector (FID; Agilent Technologies, Palo Alto, CA). The FAME were separated on a Supelcowax $30 \mathrm{~m} \times$ $250 \mu \mathrm{m} \times 0.2 \mu \mathrm{m}$ column (Supelco Inc., Bellefonte, PA). Helium (99.9999\%, AGA, Oslo, Norway) was used as carrier gas at a constant flow of $3.25 \mathrm{~mL} / \mathrm{min}$. The $\mathrm{GC}$ oven temperature was $70^{\circ} \mathrm{C}$ for $0.5 \mathrm{~min}$, raised by $30^{\circ} \mathrm{C} / \mathrm{min}$ to $170^{\circ} \mathrm{C}$, thereafter $1.5^{\circ} \mathrm{C} / \mathrm{min}$ to 221 , and finally $50^{\circ} \mathrm{C} / \mathrm{min}$ to 255 for $5 \mathrm{~min}$.

The chemical composition of the feed was analyzed as described by Eknæs et al. (2017).

\section{Milk Sampling}

Milk was sampled 6 times throughout the lactation period at 30,60, 90, 120, 190, and 230 DIM. The goats were milked at 0600 and $1530 \mathrm{~h}$. Milk yield was measured on 3 subsequent days every second week during indoor feeding and on 2 subsequent days every fourth week during mountain grazing. Because milk yield was lower in the evening, morning and evening milks were mixed in the ratio 1.5:1. Preparation and analysis were performed on milk stored at $4^{\circ} \mathrm{C}$ for $84 \mathrm{~h}$ (age of milk when processed by the dairies), without preservatives unless otherwise specified. At 190 DIM, the goats were on summer mountain pasture and because of limited laboratory facilities, the milk samples were stored in Styrofoam boxes with crushed ice and cooling elements during the 5-h transfer by car to the University (Ås, Norway) for preparation and analyses.

\section{Total Content of Fat and FFA}

The total content of fat and FFA in milk were analyzed by FTIR/milkoscan (MilkoScan Combifoss 6500; Foss, Hillerød, Denmark). To avoid microbial growth, 1 tablet of Bronopol (2-bromo-2-nitropropane-1, 3-diol; D\&F Control Systems Inc., Dublin, CA) was added to the samples, which were kept at $4^{\circ} \mathrm{C}$ until analysis. The fat content was measured in milk stored for $36 \mathrm{~h}$. To study lipolysis in milk during storage, the content of FFA was measured in raw milk samples after 36 and 84 h. To obtain a 0 -sample, the content of FFA was measured in milk pasteurized $\left(63^{\circ} \mathrm{C} / 30 \mathrm{~min}\right)$ immediately after milking (pasteurization inactivates LPL activity).

\section{Extraction, Separation, and Analysis of Milk Lipids}

The total lipids were extracted from $1 \mathrm{~mL}$ of milk as described by Steinshamn et al. (2014) using a modified method of Folch et al. (1957). Internal standards (trinonadecanoin, $2.5 \mathrm{mg}$, and trinonadecanoic acid, $0.2 \mathrm{mg}$; Larodan Fine Chemicals, Malmö, Sweden) dissolved in chloroform were added to the samples before lipid extraction.

The extracted lipids were re-dissolved in hexane:chloroform:methanol (95:3:2, $\mathrm{vol} / \mathrm{vol})$ and loaded on 500-mg aminopropyl cartridges (Hypersep spe, Thermo Scientific, Bellefonte, PA) for solid-phase extraction. The cartridges were conditioned with $7 \mathrm{~mL}$ of hexane before loading. Neutral lipids (mainly TG) were eluted with $5 \mathrm{~mL}$ of chloroform, and then FFA

Table 1. Chemical and fatty acid composition of control concentrate, concentrates with added $8 \%$ fatty acids from palm oil (POFA) or rapeseed oil (RSO), and silage

\begin{tabular}{lcccc}
\hline & \multicolumn{3}{c}{ Concentrate } & \\
\cline { 2 - 3 } Item & Control & POFA & RSO & Silage \\
\hline DM $(\mathrm{g} / \mathrm{kg})$ & 912 & 889 & 897 & 253 \\
Chemical composition $(\mathrm{g} / \mathrm{kg}$ of $\mathrm{DM})$ & & & & \\
CP & 196 & 191 & 195 & 138 \\
Crude fat & 22 & 107 & 110 & 34 \\
Starch & 343 & 280 & 299 & \\
aNDF & 187 & 172 & 168 & 531 \\
Total N & 32.5 & 34.5 & 34.9 & 23.4 \\
Ash & 73 & 72.5 & 69.5 & 77.2 \\
Fatty acid composition (g/100 g of total FAME) & & & & \\
C14:0 & 0.3 & 0.7 & 0.1 & 0.5 \\
C16:0 & 17.9 & 52.6 & 8.1 & 13.3 \\
C16:1 cis-9 & 0.3 & 0.1 & 0.3 & 1.5 \\
C18:0 & 1.8 & 25.9 & 2.4 & 1.6 \\
C18: 1 cis-9 & 15.1 & 4.5 & 48.9 & 3.1 \\
C18: 1 cis-11 & 2.3 & 0.7 & 3.1 & 0.5 \\
C18:2 cis-9,12 & 37.9 & 8 & 22.9 & 14.8 \\
C18:3 cis-9,12,15 & 4.5 & 1 & 6.9 & 41 \\
Unidentified FAME & 0.2 & 0.3 & 0.6 & 0.8 \\
\hline
\end{tabular}

${ }^{1} \mathrm{NDF}$ assayed with $\alpha$ amylase and expressed exclusive of residual ash. 
were eluted with $5 \mathrm{~mL}$ of $2 \%$ acetic acid in diethyl ether. The solvents were evaporated to dryness under a gentle stream of $\mathrm{N}_{2}$.

Transesterification and esterification of fatty acids from TG and FFA, respectively, were performed according to Devle et al. (2014), and FAME in hexane were transferred to $\mathrm{GC}$ vials and stored at $-20^{\circ} \mathrm{C}$ until analysis.

The FAME were analyzed using a Carlo Erba GC 8000 GC equipped with a Carlo Erba EL 980 autosampler and a Carlo Erba AS V570 FID (Carlo Erba Instruments, Milano, Italy). The column used was a 50-m CP-Sil 88 capillary column with an inner diameter of $0.25 \mathrm{~mm}$ and $0.20-\mu \mathrm{m}$ film thickness (Varian, Agilent Technologies, Matriks, Norway). Helium (99.9999\%, AGA, Oslo, Norway) was used as carrier gas at a constant pressure of $75 \mathrm{kPa}$. The injected sample $(1 \mu \mathrm{L})$ was split in a ratio of $1: 25$. The GC oven temperature was $60^{\circ} \mathrm{C}$ for $3 \mathrm{~min}$, raised by $10^{\circ} \mathrm{C} / \mathrm{min}$ to $140^{\circ} \mathrm{C}$ and held for $1 \mathrm{~min}$, raised by $10^{\circ} \mathrm{C} / \mathrm{min}$ to $160^{\circ} \mathrm{C}$ and held for $1 \mathrm{~min}$, and finally raised by $2.5^{\circ} \mathrm{C} / \mathrm{min}$ to $210^{\circ} \mathrm{C}$ and held for $20 \mathrm{~min}$. The FID signals were transferred to a Total Chrom workstation for interpretation and calibration. The FAME were identified by comparing the retention time of standards (Larodan Fine Chemicals; Sigma-Aldrich, St. Louis, MO) in addition to fatty acid profiles of goat milk obtained by GC-MS in a previous study (Steinshamn et al., 2014).

It is important to note that use of polypropylene tubes is a common practice in most laboratories today; however, in contact with organic solvents, fatty acids are released from the material. We detected considerable amounts of C16:0 and C18:0 fatty acids in blank samples originating from both the tubes and the SPE cartridges; these fatty acids were therefore omitted from the results. This problem was only observed in the fraction containing the FFA; the blanks from the fraction of neutral lipids (TG) were free from contamination. We strongly recommend use of acid-washed glassware for sample preparation of FFA and a frequent control of blank samples.

\section{Measurement of LPL Activity}

The LPL activity was measured in milk sampled at $30,60,120,190$, and $230 \mathrm{DIM}$ and kept at $-20^{\circ} \mathrm{C}$ before analysis. Activity of LPL (EC 3.1.1.34) was measured using an artificial emulsion containing $\left[{ }^{3} \mathrm{H}\right]$-triolein (Bernard et al., 2005).

\section{Measurement of MFG Size and Composition of the MFGM}

The size of the milk fat globules was measured by laser light scattering using a Mastersizer 2000 (Malvern
Instruments, Malvern, UK). The method is previously described by Michalski et al. (2001) with some modifications: $0.1 \%$ SDS solution was replaced by MilliQ water.

The composition of phospholipids and cholesterol in the MFGM were analyzed by Vitas AS (Oslo, Norway). Six milk samples (3 with high and 3 with low content of FFA) from the sampling at 90 DIM were chosen for this analysis, and only milk from goats on the POFA feed was used to omit confounding factors such as lactation stage and feed. The milk samples were kept at $-20^{\circ} \mathrm{C}$ before analysis. For identification and quantification of polar lipids and sphingomyelin, samples were accurately weighed, dissolved in isopropanol, shaken, and centrifuged $\left(4,000 \times g\right.$ at $10^{\circ} \mathrm{C}$ for $\left.10 \mathrm{~min}\right)$ before the supernatants were transferred to new vials. The pellets were washed with isopropanol and centrifuged $(4,000$ $\times g$ at $10^{\circ} \mathrm{C}$ for $10 \mathrm{~min}$ ), and the resulting supernatants were pooled with the first ones. The supernatants were evaporated to dryness and dissolved in a mix of chloroform:methanol:water and analyzed with an Agilent 1100 normal phase liquid chromatography system using an evaporative light scattering detector. Separation was performed on a PVC-SIL-NP $250 \times 4.6$ mm HPLC column (YMC, Dinslaken, Germany) using hexane, isopropanol, acetonitrile, chloroform, tertbutyl methyl ether, water, and acetic acid as mobile phase. Analytes were calibrated against known standards (Lipoid GmbH, Köln, Germany). Samples for quantification of cholesterol were accurately weighed and dissolved in methanol and a sodium hydroxide solution, and then incubated for $60 \mathrm{~min}$ at $50^{\circ} \mathrm{C}$ to hydrolyze cholesteryl esters to free cholesterol and then centrifuged. Cholesterol was determined by an Agilent reversed-phase liquid chromatography system using a diode array detector. Separation was performed on an Eclipse XDB-C8 $150 \times 4.6$ particle size $5-\mu \mathrm{m}$ column from Agilent using methanol with ammonium acetate as mobile phase. Analytes were calibrated against standards from Sigma-Aldrich.

\section{Sensory Evaluation of Milk}

Three panelists trained in sensory evaluation of goat milk performed the analysis. The analysis was done by scoring using a scale from 1 to 5 , where 1 indicates pronounced flavor deviation and 5 indicates good milk without off-flavors. The panel's average score for each sample was used in calculations.

\section{Statistical Analysis}

Analysis of variance was performed using the MIXED procedure (Littell et al., 1998) of SAS (ver. 9.4, SAS In- 
stitute Inc., Cary, NC). Samples were collected 4 times (3 times for LPL activity) from each goat during the experimental period; therefore, a repeated-measures procedure was used. The covariance structure of the repeated measurements was chosen by comparing potential structures using Akaike's and Schwarz's Bayesian information criteria (Wolfinger, 1996). Variance components covariance structure proved useful for all the milk data. The values at 60 DIM were used as a covariate. The ANOVA with repeated measures of the milk data was performed according to the following model:

$$
\begin{aligned}
Y_{i j k l}=\mu & +A_{i}+B_{j}+A \times B_{(i j)}+C_{k}+A \\
& \times C_{(i k)}+d\left(A_{i}, \mathrm{C}_{k}\right)+\varepsilon_{i j k l},
\end{aligned}
$$

where $Y_{i j k l}$ is the dependent variable; $\mu$ is the intercept; $A_{i}$ is the fixed effect of concentrate type, $i=1,2,3$ (CON, POFA, RSO); $B_{j}$ is the fixed effect of DIM, $j=$ $1,2, \ldots, 4$ (DIM 90, 120, 190, 230); $A \times B_{(i j)}$ is the interaction between concentrate type $i$ and DIM $j ; C_{k}$ is the fixed effect of genotype at the CSN1S1 locus, $k=1,2$ (E12-00, E12-01); $A \times C_{(i k)}$ is the interaction between concentrate type $i$ and genotype $k ; d\left(A_{i}, C_{k}\right)$ is random effect of goat within concentrate type and genotype and $\varepsilon_{i j k l}$ represents the experimental error.

The difference between means was estimated by the calculated least squares means (LSM). Differences were considered statistically significant when $P<0.05$.

Principal component analysis (PCA) of the TG fatty acids composition and partial least squares regression using the FFA content and composition as $\mathrm{X}$ variables and sensory scores as $\mathrm{Y}$ variables were conducted using The Unscrambler X 10.3 (CAMO Process AS, Oslo, Norway). The fatty acid data (for TG and FFA) were standardized by dividing each response variable by its standard deviation to ensure equal contribution in the model. The sensory data were not weighted as the same scale was used during analysis. Full cross-validation was used to validate the data set.

The data from the analysis of the MFGM composition (content of phospholipids and cholesterol) of samples with high versus low content of FFA were analyzed by a 2 sample $t$-test using R Statistics (version 3.2.5; R Core Team, 2016). Differences were considered statistically significant when $P<0.05$.

\section{RESULTS AND DISCUSSION}

\section{Fat Content and Fatty Acid Composition of Triglycerides}

The fat content in milk was influenced both by DIM $(P<0.001)$ and type of lipid supplementation $(P<$
0.001). Often, a lower fat content can be explained by higher milk yield. However, the milk yield was not significantly different between any of the feeding groups, but decreased gradually during the course of lactation (Table 2). The fat content in milk was highest shortly after kidding (30 DIM) and in POFA milk (POFA > RSO > CON; Table 2). A high fat content in early lactation is in accordance with other studies (Chilliard et al., 2003; Eknæs et al., 2006). Extra dietary lipids fed to goats are known to increase the fat content in the milk (Chilliard et al., 2007; Sanz Sampelayo et al., 2007; Tudisco et al., 2015). However, differences in fat content $(P=0.02)$ between the POFA and RSO groups were not expected. One of the limitations of feeding fat supplements to dairy cows is the inhibition of their rumen microbial activity (Palmquist, 1984), which affects fiber digestion in the rumen (Palmquist, 1984) and probably depresses fiber intake (Khorasani et al., 1996). Furthermore, feeding a surplus of unsaturated fats to cows may cause milk fat depression (Bauman and Griinari, 2003; Chilliard et al., 2007). However, goats seem to tolerate addition of unsaturated fat well, and hence it is possible to alter the milk fatty acid composition by feeding (Chilliard et al., 2007). In total, 32 fatty acids were identified and quantified from the TG fraction (Tables $3,4,5$, and 6 ). The most abundant fatty acids were palmitic acid (C16:0; Table 3), stearic acid (C18:0), and oleic acid (C18:1 cis-9; Table 5). The composition of all fatty acids except arachidonic acid (C20:4 cis-5,8,11,14) were influenced by lactation stage . Moreover, the interaction between feeding group and lactation stage was significant for most fatty acids (Tables 3 to 6$)$. The contents of short- and medium-chain SFA (C4:0-C14:0) were highest in early and late stages of lactation, whereas UFA were highest in mid lactation. The PCA separated goats into 3 distinct clusters according to feed group (Figure 1). Comparison of the score plot (goats; Figure 1A) with the loading plot (milk fatty acids; Figure 1B) shows that goats in the CON group produced milk fat with a higher content of de novo synthesized SFA with $<16$ carbon atoms (except for C4:0). Moreover, the CON milk fat had a higher proportion of odd- and branched-chain fatty acids (Tables 3 and 4) compared with the POFA and RSO groups. The odd- and branched-chain fatty acids originate from ruminal metabolism of branched-chain AA, propionate, and butyrate (Chilliard et al., 2003). The higher content of de novo synthesized fatty acids and odd- and branched-chain fatty acids in CON milk fat than in POFA and RSO milk fat is probably because supplementation of dietary fat inhibits de novo synthesis and alters the ruminal microflora. A higher content of $\mathrm{C} 16: 0$ and $\mathrm{C} 16: 1$ cis throughout lactation characterized the POFA milk fat compared with the CON and 
RSO milks (Table 3, Figure 1). These results are in accordance with previous results using the same source of saturated lipids (Eknæs et al., 2009) and reflects the high C16:0 in POFA, and the $\Delta^{9}$-desaturation of a part of C16:0. The RSO milk fat had higher proportions of fatty acids with 18 or more carbons, especially C18:0 and $\mathrm{C} 18: 1$ cis-9. However, linoleic $(\mathrm{C} 18: 2$ cis-9,12) and linolenic acid (C18:3 cis-9,12,15) were higher in CON milk, but only when the goats were grazing mountain pastures, and the content of C20:4 cis-5,8,11,14 was not influenced by feed (Table 5). This is most likely due to the almost complete biohydrogenation in the rumen of linoleic and linolenic acids from dietary rapeseed oil, which are transformed into C18:0 and several cis or trans intermediates (Chilliard et al., 2007).

The shift in basal diet from silage to mountain pasture from 130 to 200 DIM caused an increase in long-chain SFA (C17, C18, C20, and C22), vaccenic, linoleic, and linolenic acids at the expense of mediumchain (C10-C14) and odd- and branched-chain fatty acids in milk fat from all feed groups (Tables 3 to 6 ) and C16:0 in CON and POFA groups (Table 3). The putative effects of lactation stage and of the change in basal forage from silage to mountain pasture at 190 DIM were confounded. However, the different milk fatty acid composition observed at 190 DIM is more likely an effect of grazing rather than lactation stage because lactation was in its slowly declining phase and similar effects of changing the basal diet from hay or silage to grass were reported previously (e.g., Chilliard et al., 2007; Steinshamn et al., 2014).

Pasture and supplementation of rapeseed oil increased the content of long-chain and unsaturated fatty acids in the milk fat in present study, and intake of such fatty acids is recommended for human consumption by health authorities and nongovernmental organizations (FAO, 2010). Moreover, some fatty acids, such as branchedchain fatty acids, vaccenic acid (C18:1 trans-11), and CLA, are thought to have health-promoting properties (Shingfield et al., 2008).

If milk is to be processed into products such as cheese and butter, a high proportion of UFA may result in products with a softer texture. Protein composition and cheesemaking properties of the POFA and RSO milks

Table 2. Milk yield, fat content, size of milk fat globules (MFG), lipoprotein lipase activity (LPL), concentration of free fatty acids after 84 h of storage $\left(\mathrm{FFA}_{84 \mathrm{~h}}\right)$, and flavor scores in milk from goats fed a control $(\mathrm{CON})$ feed with no extra fat, or concentrates supplemented with either palm (POFA) or rapeseed oil (RSO)

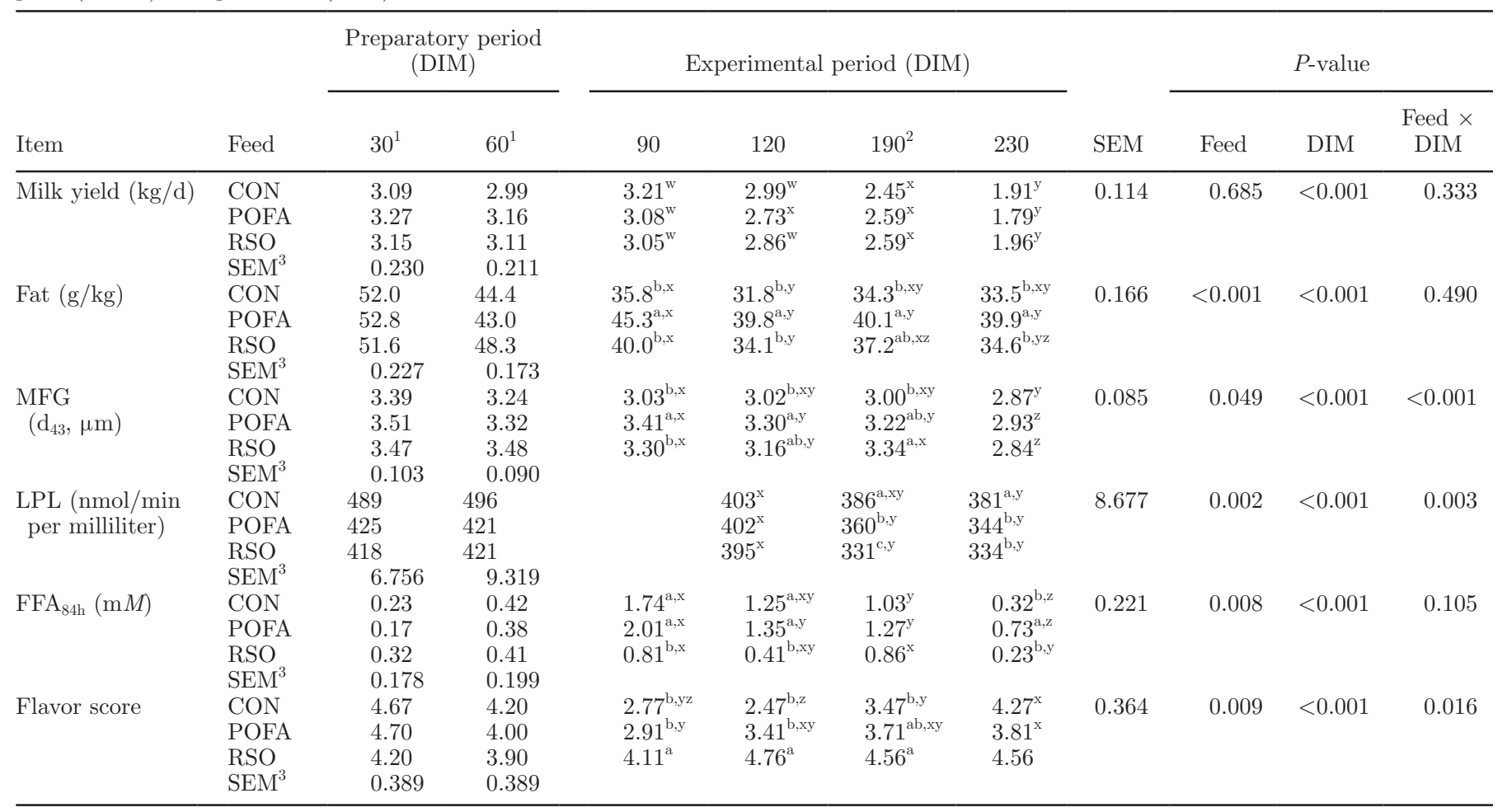

\footnotetext{
${ }^{a-c}$ LSM within a column with different letters are significantly different $(P<0.05)$ from each other.

${ }^{\mathrm{w}-\mathrm{L}} \mathrm{LSM}$ within a row with different superscript letters are significantly different $(P<0.05)$ from each other.

${ }^{1}$ All goats received the control concentrate in the preparatory period.

${ }^{2}$ Mountain pasture.

${ }^{3}$ Standard error of mean for the preparatory period.
} 
Table 3. Short- and medium-chain fatty acids (\% of total FA in triglycerides) in milk from goats fed either a concentrate with palm (POFA) or rapeseed oil (RSO) or a control (CON) feed with no extra fat

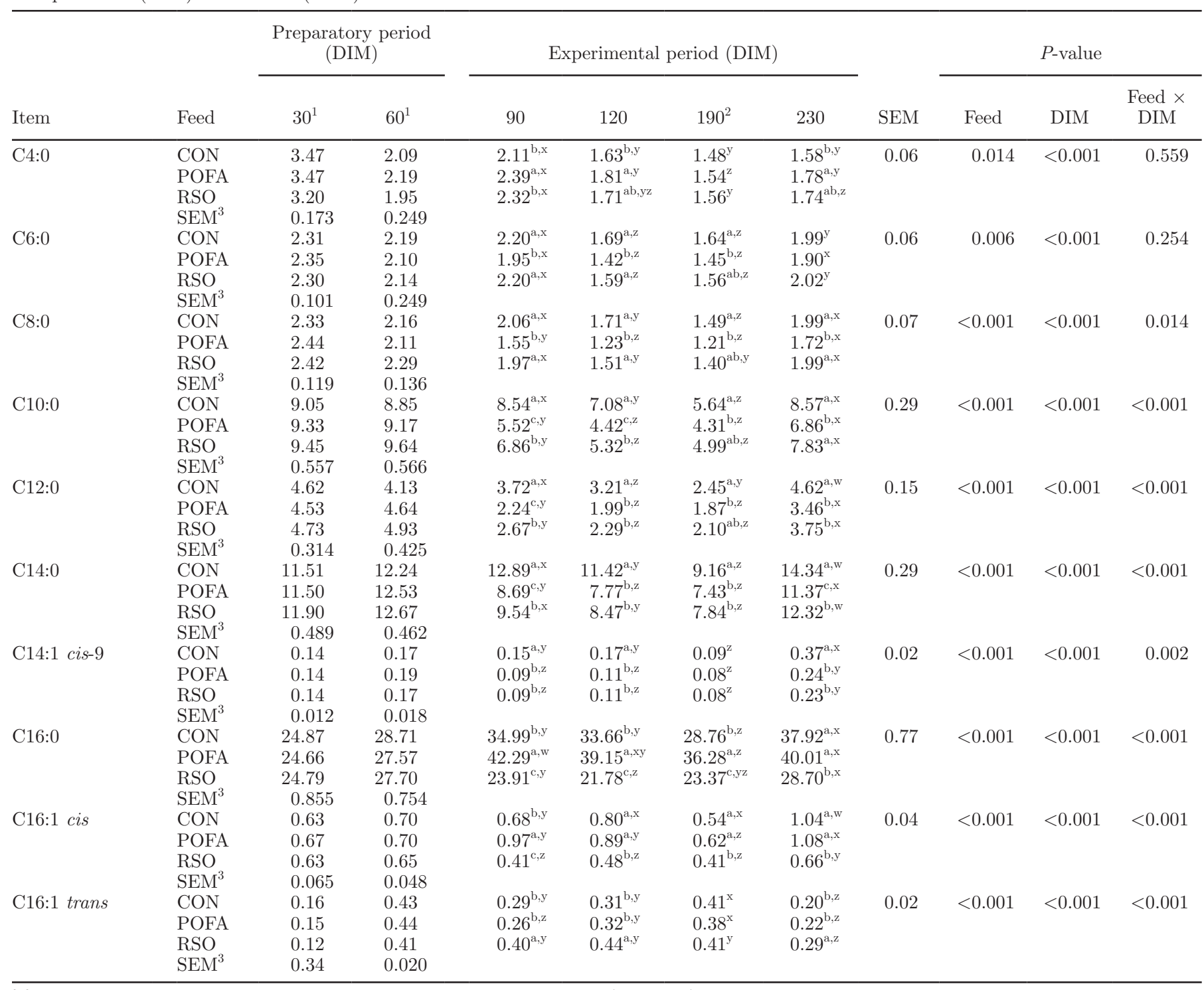

${ }^{a-c}$ LSM within a column with different letters are significantly different $(P<0.05)$ from each other.

${ }^{\mathrm{w}-\mathrm{z}} \mathrm{LSM}$ within a row with different superscript letters are significantly different $(P<0.05)$ from each other.

${ }^{1}$ All goats received the control concentrate in the preparatory period.

${ }^{2}$ Mountain pasture.

${ }^{3}$ Standard error of mean for the preparatory period.

were analyzed in a parallel study. A doughy cheese with a high moisture content was obtained from milk of goats fed rapeseed oil, whereas cheese with a lower moisture content, better texture, and a higher content of free amino acids, indicating a higher proteolysis rate, was obtained from milk of goats fed palm oil (Inglingstad et al., 2016). Because no differences in the protein composition were detected, these effects in the final cheeses are likely to be explained by the different fatty acid composition in RSO and POFA milks. The fatty acids that influence cheese texture are mainly C16:0 and C18:1 cis-9 (Coppa et al., 2011), which are the most abundant SFA and UFA in POFA and RSO milks, respectively. However, the influence of fatty acid composition on content of free AA and cheese ripening has not previously been reported in the literature, to our knowledge, and why different fatty acid composition results in different content of free AA is yet unknown.

Goat milk contains a higher proportion of the "goat fatty acids" - caproic (C6:0), caprylic (C8:0), and capric (C10:0) acids - compared with other ruminant milk (Chilliard et al., 2003). These fatty acids were influ- 
Table 4. Odd- and branched-chain fatty acids (\% of total FA) in milk from goats fed either palm (POFA) or rapeseed oil (RSO) or a control $(\mathrm{CON})$ feed with no extra fat

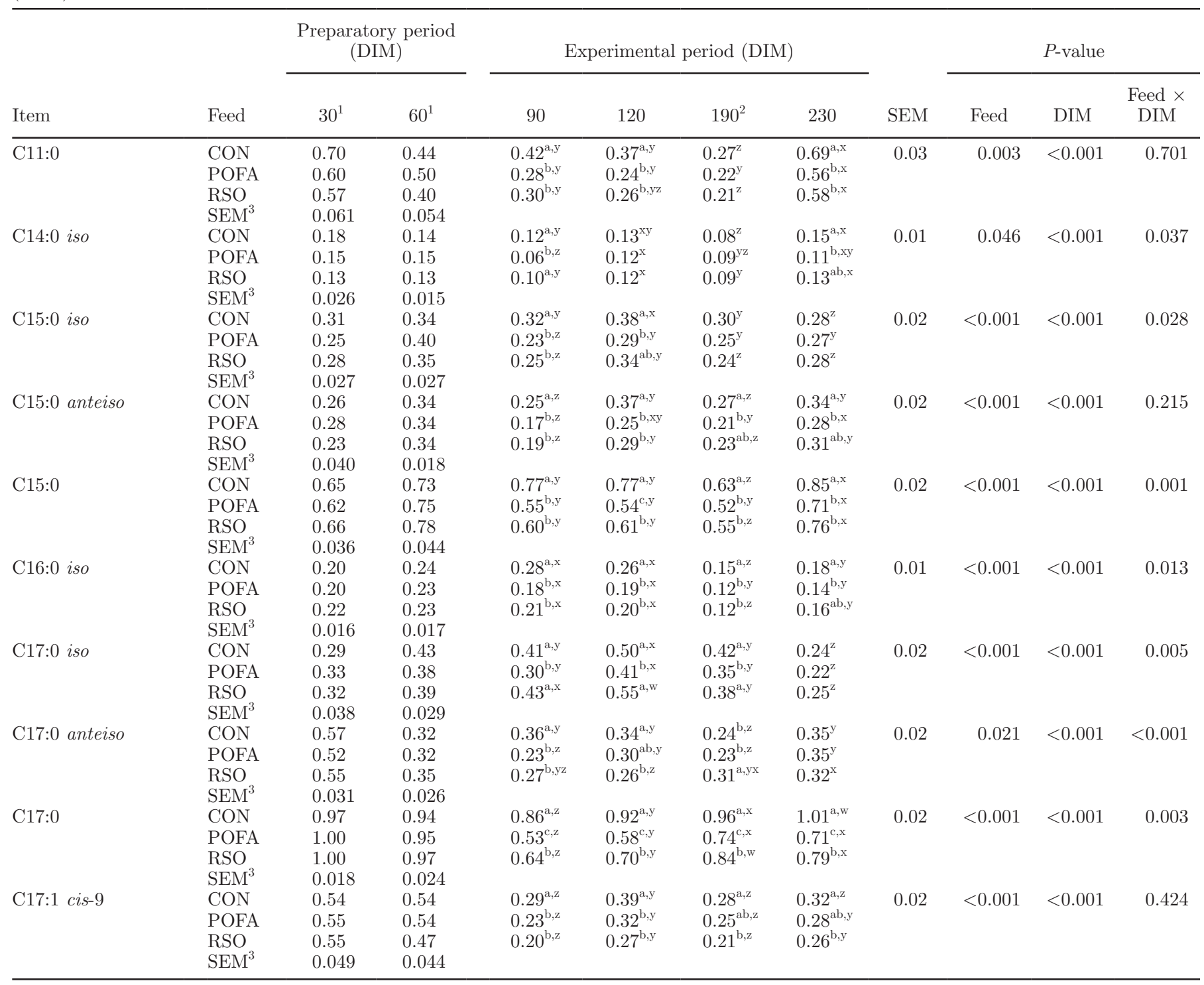

${ }^{\mathrm{a}-\mathrm{C}} \mathrm{LSM}$ within a column with different letters are significantly different $(P<0.05)$ from each other.

${ }^{\mathrm{w}-\mathrm{z}} \mathrm{LSM}$ within a row with different superscript letters are significantly different $(P<0.05)$ from each other.

${ }^{1}$ All goats received the control concentrate in the preparatory period.

${ }^{2}$ Mountain pasture.

${ }^{3}$ Standard error of mean for the preparatory period.

enced by feed, DIM, and genotype. The proportion of goat fatty acids was higher in CON milk fat (Table 6) and in milk fat from goats of E12-01 genotype, whereas C16:0 was higher in milk fat from E12-00 goats (Table 7).

\section{Mean Diameter of the MFG}

The mean size of the MFG decreased during lactation from $3.46 \mu \mathrm{m}$ at 30 DIM to $2.88 \mu \mathrm{m}$ at 230 DIM, and a similar effect of lactation on the MFG size has been reported in bovine milk (Wiking et al., 2004). A decline in MFG size with increasing intake of fresh grass (Couvreur et al., 2006) and unsaturated lipids (Lopez et al., 2008) has been reported in cow milk. However, we observed no decrease in MFG size at the end of the grazing period (at 190 DIM, Table 2). The average size of MFG has been reported to vary between goat breeds; smaller MFG were reported in milk from French Alpine $(2.76 \mu \mathrm{m}$; Attaie and Richter, 2000) and Sarda $(2.73 \mu \mathrm{m})$ than in Saanen $(3.63 \mu \mathrm{m}$; Pisanu et al., 2013). The MFG size of Norwegian dairy goats seems 
to be in between those breeds, with an average of 3.2 positive relationship between fat content and the mean $\mu \mathrm{m}$ in mid lactation (120 DIM). The above-mentioned diameter of the MFG of goats (Cebo et al., 2012), cows effects of breed, diet, and lactation stage are probably (Wiking et al., 2004), and buffaloes (Ménard et al., confounded with fat content. Several authors report a 2010), a trend also confirmed in our study $(\mathrm{r}=0.72$,

Table 5. Long-chain fatty acids (\% of total FA in triglycerides) in milk from goats fed either palm (POFA) or rapeseed oil (RSO), or a control $(\mathrm{CON})$ feed with no extra fat

\begin{tabular}{|c|c|c|c|c|c|c|c|c|c|c|c|}
\hline \multirow[b]{2}{*}{ Item } & \multirow[b]{2}{*}{ Feed } & \multicolumn{2}{|c|}{$\begin{array}{l}\text { Preparatory period } \\
\text { (DIM) }\end{array}$} & \multicolumn{4}{|c|}{ Experimental period (DIM) } & \multirow[b]{2}{*}{ SEM } & \multicolumn{3}{|c|}{$P$-value } \\
\hline & & $30^{1}$ & $60^{1}$ & 90 & 120 & $190^{2}$ & 230 & & Feed & DIM & $\begin{array}{c}\text { Feed } \times \\
\text { DIM }\end{array}$ \\
\hline C18:0 & $\begin{array}{l}\text { CON } \\
\text { POFA } \\
\text { RSO } \\
\text { SEM }^{3}\end{array}$ & $\begin{array}{l}9.89 \\
9.20 \\
9.13 \\
1.096\end{array}$ & $\begin{array}{l}9.14 \\
9.61 \\
9.34 \\
0.640\end{array}$ & $\begin{array}{r}7.82^{\mathrm{c}, \mathrm{y}} \\
9.45^{\mathrm{b}, \mathrm{y}} \\
15.76^{\mathrm{a}, \mathrm{y}}\end{array}$ & $\begin{array}{r}8.71^{\mathrm{c}, \mathrm{x}} \\
10.65^{\mathrm{b}, \mathrm{x}} \\
17.02^{\mathrm{a}, \mathrm{x}}\end{array}$ & $\begin{array}{l}15.02^{\mathrm{b}, \mathrm{w}} \\
14.18^{\mathrm{b}, \mathrm{w}} \\
19.54^{\mathrm{a}, \mathrm{w}}\end{array}$ & $\begin{array}{l}4.71^{\mathrm{b}, \mathrm{z}} \\
6.13^{\mathrm{b}, \mathrm{z}} \\
9.48^{\mathrm{a}, \mathrm{z}}\end{array}$ & 0.46 & $<0.001$ & $<0.001$ & $<0.001$ \\
\hline C18:1 trans -9 & $\begin{array}{l}\text { CON } \\
\text { POFA } \\
\text { RSO } \\
\text { SEM }^{3}\end{array}$ & $\begin{array}{l}0.33 \\
0.33 \\
0.30 \\
0.042\end{array}$ & $\begin{array}{l}0.33 \\
0.31 \\
0.33 \\
0.031\end{array}$ & $\begin{array}{l}0.26^{\mathrm{c}, \mathrm{y}} \\
0.52^{\mathrm{b}, \mathrm{y}} \\
0.90^{\mathrm{a}, \mathrm{x}}\end{array}$ & $\begin{array}{l}0.31^{\mathrm{c,y}} \\
0.65^{\mathrm{b}, \mathrm{x}} \\
1.01^{\mathrm{a,w}}\end{array}$ & $\begin{array}{l}0.40^{\mathrm{c,x}} \\
0.57^{\mathrm{b}, \mathrm{y}} \\
0.80^{\mathrm{a}, \mathrm{y}}\end{array}$ & $\begin{array}{l}0.16^{\mathrm{c}, \mathrm{z}} \\
0.40^{\mathrm{b}, \mathrm{z}} \\
0.49^{\mathrm{a}, \mathrm{z}}\end{array}$ & 0.02 & $<0.001$ & $<0.001$ & $<0.001$ \\
\hline C18:2 trans $-9,12$ & $\begin{array}{l}\text { CON } \\
\text { POFA } \\
\text { RSO } \\
\text { SEM }^{3}\end{array}$ & $\begin{array}{l}0.17 \\
0.15 \\
0.17 \\
0.012\end{array}$ & $\begin{array}{l}0.17 \\
0.18 \\
0.17 \\
0.014\end{array}$ & $\begin{array}{l}0.13^{\mathrm{b}, \mathrm{z}} \\
0.12^{\mathrm{b}, \mathrm{z}} \\
0.26^{\mathrm{a}, \mathrm{z}}\end{array}$ & $\begin{array}{l}0.18^{\mathrm{b}, \mathrm{y}} \\
0.16^{\mathrm{b}, \mathrm{y}} \\
0.34^{\mathrm{a}, \mathrm{y}}\end{array}$ & $\begin{array}{l}0.18^{\mathrm{b}, \mathrm{y}} \\
0.15^{\mathrm{b}, \mathrm{y}} \\
0.27^{\mathrm{a}, \mathrm{z}}\end{array}$ & $\begin{array}{l}0.12^{\mathrm{b}, \mathrm{z}} \\
0.12^{\mathrm{b}, \mathrm{z}} \\
0.28^{\mathrm{a}, \mathrm{z}}\end{array}$ & 0.01 & $<0.001$ & $<0.001$ & 0.004 \\
\hline C18:2 cis-9,trans- 11 & $\begin{array}{l}\text { CON } \\
\text { POFA } \\
\text { RSO } \\
\text { SEM }^{3}\end{array}$ & $\begin{array}{l}0.58 \\
0.58 \\
0.62 \\
0.034\end{array}$ & $\begin{array}{l}0.60 \\
0.61 \\
0.59 \\
0.034\end{array}$ & $\begin{array}{l}0.54^{\mathrm{b}, \mathrm{z}} \\
0.31^{\mathrm{c}, \mathrm{z}} \\
0.66^{\mathrm{a}, \mathrm{z}}\end{array}$ & $\begin{array}{l}0.77^{\mathrm{a}, \mathrm{x}} \\
0.45^{\mathrm{b}, \mathrm{y}} \\
0.86^{\mathrm{a}, \mathrm{y}}\end{array}$ & $\begin{array}{l}0.64^{\mathrm{a}, \mathrm{y}} \\
0.49^{\mathrm{b}, \mathrm{y}} \\
0.71^{\mathrm{a}, \mathrm{z}}\end{array}$ & $\begin{array}{l}0.59^{\mathrm{a}, \mathrm{yz}} \\
0.43^{\mathrm{b}, \mathrm{y}} \\
0.63^{\mathrm{a}, \mathrm{z}}\end{array}$ & 0.04 & $<0.001$ & $<0.001$ & 0.019 \\
\hline C18:3 cis-9,12,15 & $\begin{array}{l}\text { CON } \\
\text { POFA } \\
\text { RSO } \\
\text { SEM }^{3}\end{array}$ & $\begin{array}{l}0.41 \\
0.47 \\
0.46 \\
0.049\end{array}$ & $\begin{array}{l}0.42 \\
0.44 \\
0.43 \\
0.023\end{array}$ & $\begin{array}{l}0.32^{\mathrm{a}, \mathrm{z}} \\
0.21^{\mathrm{a}, \mathrm{z}} \\
0.34^{\mathrm{a}, \mathrm{z}}\end{array}$ & $\begin{array}{l}0.42^{\mathrm{a}, \mathrm{y}} \\
0.30^{\mathrm{b}, \mathrm{y}} \\
0.46^{\mathrm{a}, \mathrm{y}}\end{array}$ & $\begin{array}{l}0.94^{\mathrm{a}, \mathrm{x}} \\
0.67^{\mathrm{c}, \mathrm{x}} \\
0.77^{\mathrm{b}, \mathrm{x}}\end{array}$ & $\begin{array}{l}0.32^{\mathrm{a}, \mathrm{z}} \\
0.24^{\mathrm{b}, \mathrm{z}} \\
0.35^{\mathrm{a}, \mathrm{z}}\end{array}$ & 0.02 & $<0.001$ & $<0.001$ & $<0.001$ \\
\hline $\mathrm{C} 20: 4$ cis-5,8,11,14 & $\begin{array}{l}\text { CON } \\
\text { POFA } \\
\text { RSO } \\
\text { SEM }^{3}\end{array}$ & $\begin{array}{l}0.19 \\
0.13 \\
0.15 \\
0.023\end{array}$ & $\begin{array}{l}0.11 \\
0.11 \\
0.12 \\
0.016\end{array}$ & $\begin{array}{l}0.10^{\mathrm{ab}} \\
0.05^{\mathrm{b}, \mathrm{z}} \\
0.13^{\mathrm{a}}\end{array}$ & $\begin{array}{l}0.13 \\
0.07 \\
0.11\end{array}$ & $\begin{array}{l}0.13 \\
0.13^{\mathrm{y}} \\
0.10\end{array}$ & $\begin{array}{l}0.09 \\
0.04^{\mathrm{z}} \\
0.07\end{array}$ & 0.02 & 0.119 & 0.067 & 0.361 \\
\hline $\mathrm{C} 22: 0$ & $\begin{array}{l}\text { CON } \\
\text { POFA } \\
\text { RSO } \\
\text { SEM }^{3}\end{array}$ & $\begin{array}{l}0.18 \\
0.14 \\
0.15 \\
0.038\end{array}$ & $\begin{array}{l}0.15 \\
0.15 \\
0.12 \\
0.017\end{array}$ & $\begin{array}{l}0.16^{\mathrm{a}, \mathrm{y}} \\
0.12^{\mathrm{b}, \mathrm{zz}} \\
0.18^{\mathrm{a}, \mathrm{y}}\end{array}$ & $\begin{array}{l}0.18^{\mathrm{b}, \mathrm{y}} \\
0.1^{\mathrm{c}, \mathrm{y}} \\
0.23^{\mathrm{a}, \mathrm{x}}\end{array}$ & $\begin{array}{l}0.29^{\mathrm{a}, \mathrm{x}} \\
0.24^{\mathrm{b}, \mathrm{x}} \\
0.29^{\mathrm{a}, \mathrm{w}}\end{array}$ & $\begin{array}{l}0.12^{\mathrm{b}, \mathrm{z}} \\
0.08^{\mathrm{c}, \mathrm{z}} \\
0.14^{\mathrm{a}, \mathrm{z}}\end{array}$ & 0.01 & $<0.001$ & $<0.001$ & 0.456 \\
\hline
\end{tabular}

\footnotetext{
${ }^{a-c}$ LSM within a column with different letters are significantly different $(P<0.05)$ from each other.

${ }^{\mathrm{w}-\mathrm{z}}$ LSM within a row with different superscript letters are significantly different $(P<0.05)$ from each other.

${ }^{1}$ All goats received the control concentrate in the preparatory period.

${ }^{2}$ Mountain pasture.

${ }^{3}$ Standard error of mean for the preparatory period.
} 
$\mathrm{n}=186 ; P<0.0001)$. This also explains why MFG size did not decline during the grazing period, because the fat content in the milk increased at this stage. The total surface area of the MFG increases with decreasing size, and MFGM material may be a limiting factor. In this way, an increase in fat content would explain the increase in MFG size.

Polymorphism in CSN1S1 may also influence MFG size as goats of the "strong" genotype (A/A) are re- ported to have larger MFG than those of the "weak" $(0 / 0)$ genotype (Cebo et al., 2012); however, the effect of genotype in the present study was not significant (Table 7).

\section{LPL Activity and Lipolysis}

Lipoprotein lipase activity decreased between 120 and 230 DIM (Table 2), which is in agreement with a

Table 6. Fatty acid (FA) groups in milk fat from goats fed either palm (POFA) or rapeseed oil (RSO) or a control (CON) feed with no extra fat

\begin{tabular}{|c|c|c|c|c|c|c|c|c|c|c|c|}
\hline \multirow[b]{2}{*}{ Item } & \multirow[b]{2}{*}{ Feed $^{1}$} & \multicolumn{2}{|c|}{ Preparatory period } & \multicolumn{4}{|c|}{ Experimental period } & \multirow[b]{2}{*}{$\mathrm{SEM}^{2}$} & \multicolumn{3}{|c|}{$P$-value } \\
\hline & & $30^{3}$ & $60^{3}$ & 90 & 120 & $190^{4}$ & 230 & & Feed & DIM & $\begin{array}{c}\text { Feed } \times \\
\text { DIM }\end{array}$ \\
\hline $\mathrm{C} 16^{8}$ & $\begin{array}{l}\text { CON } \\
\text { POFA } \\
\text { RSO } \\
\text { SEM }^{6}\end{array}$ & $\begin{array}{c}25.87 \\
25.68 \\
25.76 \\
0.864\end{array}$ & $\begin{array}{c}30.08 \\
28.95 \\
28.99 \\
0.781\end{array}$ & $\begin{array}{l}36.22^{\mathrm{b}, \mathrm{x}} \\
43.69^{\mathrm{a}, \mathrm{w}} \\
24.95^{\mathrm{c}, \mathrm{x}}\end{array}$ & $\begin{array}{l}35.01^{\mathrm{b}, \mathrm{x}} \\
40.54^{\mathrm{a}, \mathrm{x}} \\
22.91^{\mathrm{c}, \mathrm{y}}\end{array}$ & $\begin{array}{l}29.84^{\mathrm{b}, \mathrm{y}} \\
37.40^{\mathrm{a}, \mathrm{y}} \\
24.32^{\mathrm{c}, \mathrm{xy}}\end{array}$ & $\begin{array}{l}39.32^{\mathrm{a}, \mathrm{w}} \\
41.44^{\mathrm{a}, \mathrm{x}} \\
29.82^{\mathrm{b}, \mathrm{w}}\end{array}$ & 0.771 & $<0.001$ & $<0.001$ & $<0.001$ \\
\hline $\begin{array}{l}\text { Odd- and branched- } \\
\text { chain }^{9}\end{array}$ & $\begin{array}{l}\text { CON } \\
\text { POFA } \\
\text { RSO } \\
\text { SEM }^{6}\end{array}$ & $\begin{array}{l}4.67 \\
4.50 \\
4.50 \\
0.123\end{array}$ & $\begin{array}{l}4.42 \\
4.56 \\
4.45 \\
0.117\end{array}$ & $\begin{array}{l}4.09^{\mathrm{a}, \mathrm{x}} \\
2.70^{\mathrm{c}, \mathrm{z}} \\
3.20^{\mathrm{b}, \mathrm{y}}\end{array}$ & $\begin{array}{l}4.44^{\mathrm{a}, \mathrm{w}} \\
3.19^{\mathrm{c}, \mathrm{x}} \\
3.61^{\mathrm{b}, \mathrm{x}}\end{array}$ & $\begin{array}{l}3.61^{\mathrm{a}, \mathrm{y}} \\
2.93^{\mathrm{c}, \mathrm{y}} \\
3.20^{\mathrm{b}, \mathrm{y}}\end{array}$ & $\begin{array}{l}4.42^{\mathrm{a}, \mathrm{w}} \\
3.57^{\mathrm{c}, \mathrm{w}} \\
3.85^{\mathrm{b}, \mathrm{w}}\end{array}$ & 0.080 & $<0.001$ & $<0.001$ & $<0.001$ \\
\hline Long UFA ${ }^{11}$ & $\begin{array}{l}\text { CON } \\
\text { POFA } \\
\text { RSO } \\
\text { SEM }^{6}\end{array}$ & $\begin{array}{c}26.13 \\
26.99 \\
26.60 \\
1.550\end{array}$ & $\begin{array}{c}24.54 \\
23.96 \\
23.38 \\
1.377\end{array}$ & $\begin{array}{l}20.13^{\mathrm{b}, \mathrm{y}} \\
21.74^{\mathrm{b}, \mathrm{x}} \\
30.02^{\mathrm{a}, \mathrm{y}}\end{array}$ & $\begin{array}{l}24.56^{\mathrm{c}, \mathrm{x}} \\
26.63^{\mathrm{b}, \mathrm{w}} \\
34.63^{\mathrm{a}, \mathrm{w}}\end{array}$ & $\begin{array}{l}28.25^{\mathrm{b}, \mathrm{w}} \\
26.73^{\mathrm{b}, \mathrm{w}} \\
32.17^{\mathrm{a}, \mathrm{x}}\end{array}$ & $\begin{array}{l}17.88^{\mathrm{c}, \mathrm{z}} \\
21.44^{\mathrm{b}, \mathrm{x}} \\
26.61^{\mathrm{a}, \mathrm{z}}\end{array}$ & 0.665 & $<0.001$ & $<0.001$ & $<0.001$ \\
\hline$\Sigma$ MUFA & $\begin{array}{l}\text { CON } \\
\text { POFA } \\
\text { RSO } \\
\text { SEM }^{6}\end{array}$ & $\begin{array}{r}24.55 \\
25.40 \\
24.87 \\
4.79\end{array}$ & $\begin{array}{r}23.45 \\
22.96 \\
22.22 \\
4.26\end{array}$ & $\begin{array}{l}18.81^{\mathrm{c}, \mathrm{y}} \\
21.29^{\mathrm{b}, \mathrm{z}} \\
28.25^{\mathrm{a}, \mathrm{y}}\end{array}$ & $\begin{array}{l}22.68^{\mathrm{c}, \mathrm{x}} \\
25.69^{\mathrm{b}, \mathrm{y}} \\
32.29^{\mathrm{a}, \mathrm{x}}\end{array}$ & $\begin{array}{l}24.78^{\mathrm{b}, \mathrm{w}} \\
24.30^{\mathrm{b}, \mathrm{y}} \\
29.11^{\mathrm{a}, \mathrm{y}}\end{array}$ & $\begin{array}{l}17.18^{\mathrm{c}, \mathrm{z}} \\
21.13^{\mathrm{b}, \mathrm{z}} \\
25.24^{\mathrm{a}, \mathrm{z}}\end{array}$ & 0.59 & $<0.001$ & $<0.001$ & $<0.001$ \\
\hline$\Sigma$ PUFA & $\begin{array}{l}\text { CON } \\
\text { POFA } \\
\text { RSO } \\
\text { SEM }^{6}\end{array}$ & $\begin{array}{l}2.84 \\
2.81 \\
2.94 \\
0.39\end{array}$ & $\begin{array}{l}2.75 \\
2.68 \\
2.73 \\
0.32\end{array}$ & $\begin{array}{l}2.28^{\mathrm{b}, \mathrm{z}} \\
1.66^{\mathrm{c}, \mathrm{z}} \\
2.58^{\mathrm{a}, \mathrm{y}}\end{array}$ & $\begin{array}{l}2.86^{\mathrm{b}, \mathrm{y}} \\
2.10^{\mathrm{c}, \mathrm{y}} \\
3.20^{\mathrm{a}, \mathrm{x}}\end{array}$ & $\begin{array}{l}4.32^{\mathrm{a}, \mathrm{x}} \\
3.29^{\mathrm{c}, \mathrm{x}} \\
3.83^{\mathrm{b}, \mathrm{w}}\end{array}$ & $\begin{array}{l}2.08^{\mathrm{a}, \mathrm{z}} \\
1.67^{\mathrm{b}, \mathrm{z}} \\
2.32^{\mathrm{a}, \mathrm{z}}\end{array}$ & 0.10 & $<0.001$ & $<0.001$ & $<0.001$ \\
\hline
\end{tabular}

\footnotetext{
${ }^{\mathrm{a}-\mathrm{c}}$ Means within a column with different superscripts differ $(P<0.05)$.

${ }^{\mathrm{w}-\mathrm{z}}$ Means within a row with different superscripts differ $(P<0.05)$.

${ }^{1} \mathrm{CON}=$ basal concentrate containing no additional fat; POFA $=$ basal concentrate supplemented with hydrogenated palm oil enriched with palmitic acid; $\mathrm{RSO}=$ basal concentrate supplemented with rapeseed oil.

${ }^{2}$ Standard error of means for the experimental period.

${ }^{3}$ All goats received the control concentrate in the preparatory period.

${ }^{4}$ Mountain pasture.

${ }^{5}$ Sum of C6:0, C8:0, and C10:0.

${ }^{6} \mathrm{Standard}$ error of mean for the preparatory period.

${ }^{7}$ Sum of C4:0, C6:0, C8:0, C10:0, C11:0, C12:0, C14:0 iso, C14:0, C15:0 iso, C15:0 anteiso, C14:1 cis-9, and C15:0.

${ }^{8} \mathrm{Sum}$ of $\mathrm{C} 16: 0$ iso, C16:0, C16:1 trans-9, and C16:1 cis-9.

${ }^{9} \mathrm{Sum}$ of C11:0, C14:0 iso, C15:0 iso, C15:0 anteiso, C15:0, C16:0 iso, C17:0 iso, C17:0 anteiso, C17:0, and C17:1 cis-9.

${ }^{10} \mathrm{Sum}$ of $\mathrm{C} 17: 0, \mathrm{C} 18: 0, \mathrm{C} 20: 0$, and $\mathrm{C} 22: 0$.

${ }^{11}$ Sum of C17:1 cis-9, C18:1 trans-9, C18:1 trans-11, C18:1 cis-9, C20:1 cis-11, C18:2 trans-9,12, C18:2 cis-9,12, C18:3 cis-9,12,15, C18:2 cis9,trans-11, and C20:4 cis-5,8,11,14.
} 


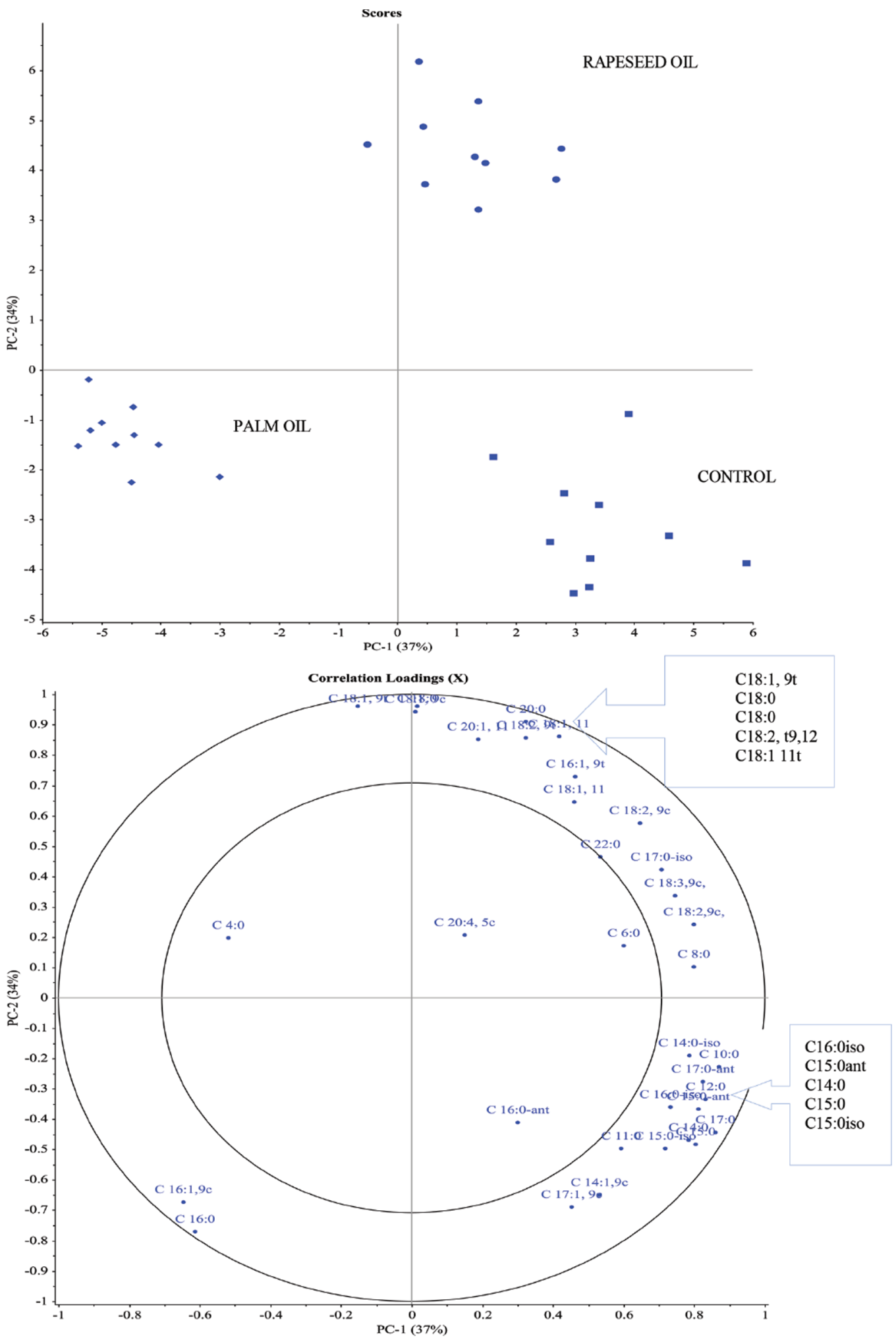

Figure 1. Principal component analysis (PCA) of the triglyceride (TG) fatty acid profile in milk at 90 DIM. The score plot (top panel) shows the distribution of the samples indicated by feeding groups: control feed with no extra fat (ם); basal concentrate supplemented with hydrogenated palm oil enriched with palmitic acid $(\bullet)$; or basal concentrate supplemented with rapeseed oil $(\bullet)$. The corresponding loading plot (bottom panel) shows the distribution of variables (fatty acids; $\mathrm{c}=$ cis, $\mathrm{t}=$ trans, ant $=$ anteiso). More than $70 \%$ of the variation was explained by principal components (PC) 1 and 2. The PCA revealed a similar distribution of the loadings and scores at 120 to 230 DIM. Color version available online. 
Table 7. Main effects on selected parameters in milk from goats either homozygous (E12-00) or heterozygous (E12-01) for the deletion in exon 12 in CSN1S1 and fed either palm (POFA) or rapeseed oil (RSO) or a control (CON) feed with no extra fat

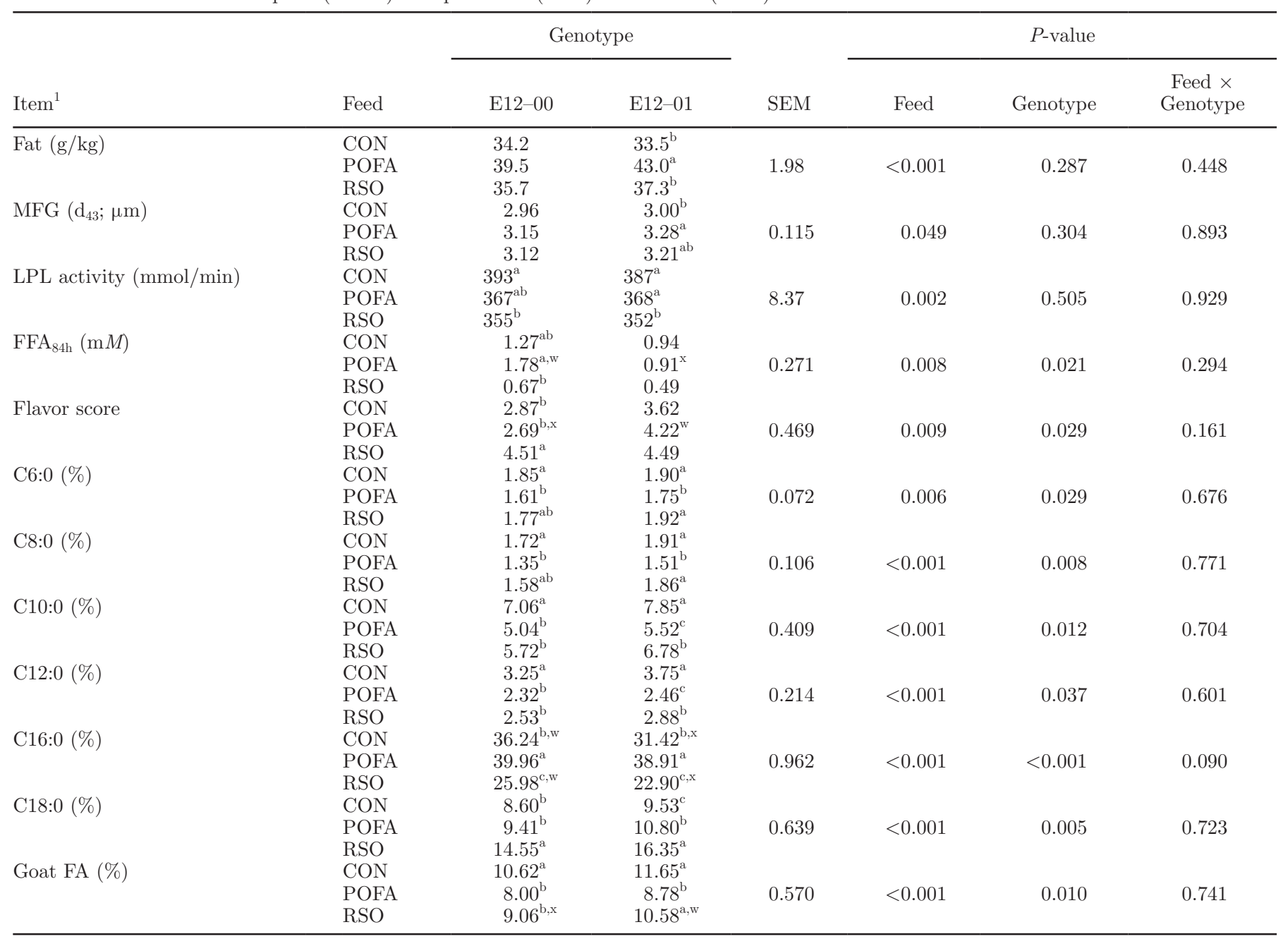

${ }^{\mathrm{a}-\mathrm{c}}$ Means within a column with different superscripts differ $(P<0.05)$.

${ }^{\mathrm{w}, \mathrm{x}}$ Means within a row with different superscripts differ $(P<0.05)$.

${ }^{1} \mathrm{MFG}=$ milk fat globule, $\mathrm{LPL}=$ lipoprotein lipase, $\mathrm{FFA}_{84 \mathrm{~h}}=$ free fatty acids after $84 \mathrm{~h}$ of storage; Goat $\mathrm{FA}=$ sum of $\mathrm{C} 6: 0, \mathrm{C} 8: 0$, and $\mathrm{C} 10: 0$.

study on cow milk (Chazal and Chilliard, 1986) but is contrary to results obtained in cow milk cream (Ahrné and Björck, 1985). Previous studies on goat milk showed low activity in early and late lactation and high LPL activity between 60 and 210 DIM (Chilliard et al., 2003). The RSO milk had lower LPL activity than CON $(P=0.001)$ and POFA $(P=0.02)$, which is supported by other studies also showing a lower LPL activity when goats were fed unsaturated lipids (Bernard et al., 2005; Ollier et al., 2009). This decrease is likely to be due to mammary LPL being more orientated toward blood capillary (for TG fatty acid uptake) than toward milk secretion when goats were fed unsaturated lipids (Chilliard et al., 2003). The LPL activity did not vary between E12-00 and E12-01 goats (Table 7). The content of FFA in milk samples that were pasteurized shortly after milking (at time 0, before the milk was cooled) was low; however, it varied among individual goat milk samples. The increase in the content of FFA from 0 to $84 \mathrm{~h}$ after milking is shown in Figure 2. Post-milking lipolysis was lower in RSO milk at 90 to 120 DIM, compared with POFA and CON milk, as previously observed (Chilliard et al., 2003; Ollier et al., 2009). This is likely to be linked to the decrease in milk LPL activity that was observed in this feeding group. The positive effect of inclusion of rapeseed oil in the feed seems to decline after 120 DIM as the differences in post-milking lipolysis were smaller between the feeding groups at 190 and 230 DIM (Figure 2). This decrease in the effect of RSO on milk lipolysis in late 
(vs. peak) lactation is likely to be due to the simultaneous decrease in lipolysis of the CON group at 190 and 230 DIM.

\section{Free Fatty Acids and Milk Flavor}

Off-flavors caused by high concentrations of FFA is challenging for the development of goat milk products. Concentrations of FFA above $1.2 \mathrm{mM}$ make the milk unsuitable for human consumption.

In early lactation, the content of FFA was low in general, although large variations were seen among goats (from 0.1 to $1.4 \mathrm{mM}$ at $30 \mathrm{DIM}$ ). The FFA content peaked in mid lactation (90 DIM, Figure 3A), which is in agreement with Chilliard et al. (2003). At this stage, some individual goats displayed an extremely high concentration (up to $4.3 \mathrm{mM}$ ) of FFA in milk. However, other goats produced milk with a low concentration $(0.1 \mathrm{mM})$ of FFA throughout the lactation, even in mid lactation. Interestingly, milk from the RSO group had a remarkably lower content of FFA $(0.8 \mathrm{~m} M)$ compared with milk from the CON $(1.7 \mathrm{~m} M, P=0.05)$ and POFA (1.9 $\mathrm{m} M, P=0.02)$ groups at $90 \mathrm{DIM}$, when the problem with high level of FFA was most prominent (Figure $3 \mathrm{~A})$. The content of FFA did not increase while the goats were grazing mountain pasture (Figure 3) which is in line with results from another study (Steinshamn et al., 2014). However, the concentration of FFA was higher in E12-00 goats compared with E12-01 goats, as expected (Table 6; Dagnachew et al., 2011).

Lactation stage, feed group, and genotype all influenced milk flavor. The best flavor scores were obtained in early and late lactation and from E12-01 goats, whereas milk at mid lactation and from E12-00 goats received lower flavor scores (Figure 3B, Table 6). Milk samples with low flavor scores (1 and 2) were described as tart or rancid. The average sensory score for RSO milk was 4.5 , which was higher than for $\operatorname{CON}(3.3, P$ $=0.004)$ and POFA $(3.5, P=0.01)$ milks (Figure 3B). This conflicts with results from another study, where a surplus of saturated fat from palm oil in the diet decreased off-flavors in the milk compared with a diet

\section{DIM}

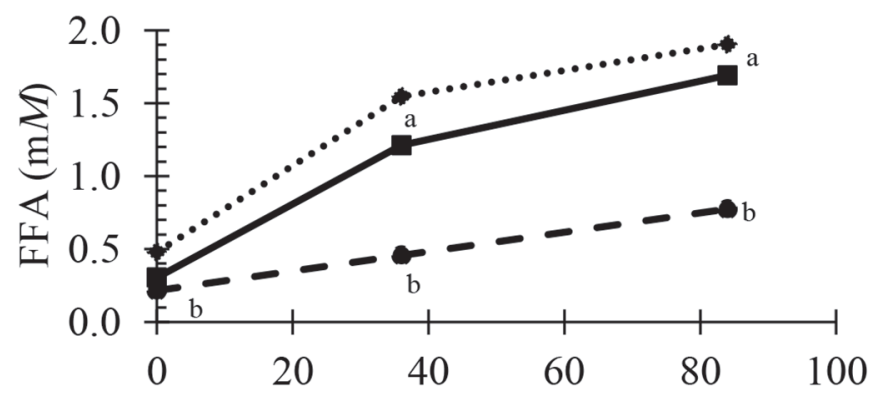

190 DIM

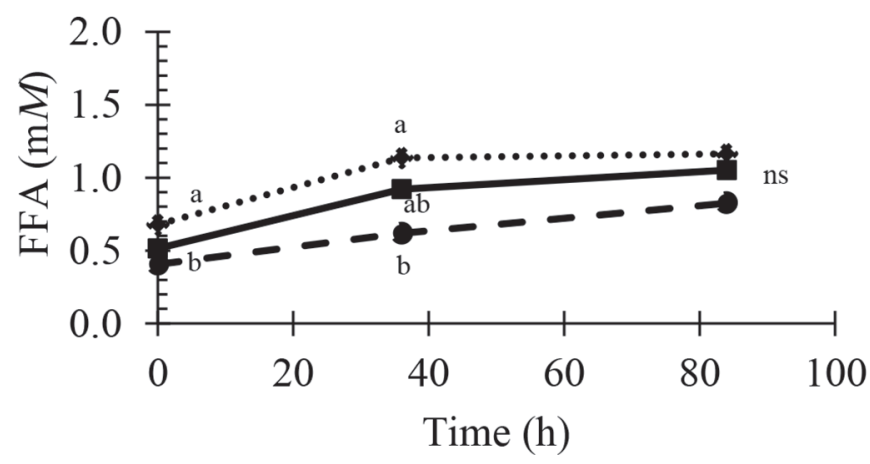

120 DIM

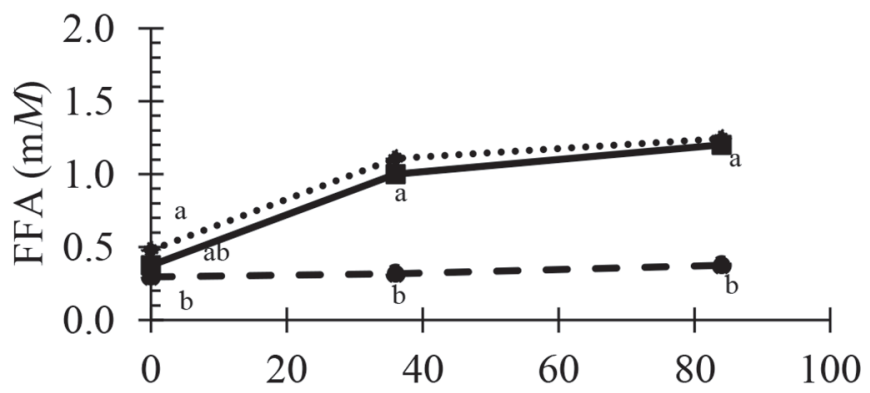

230 DIM

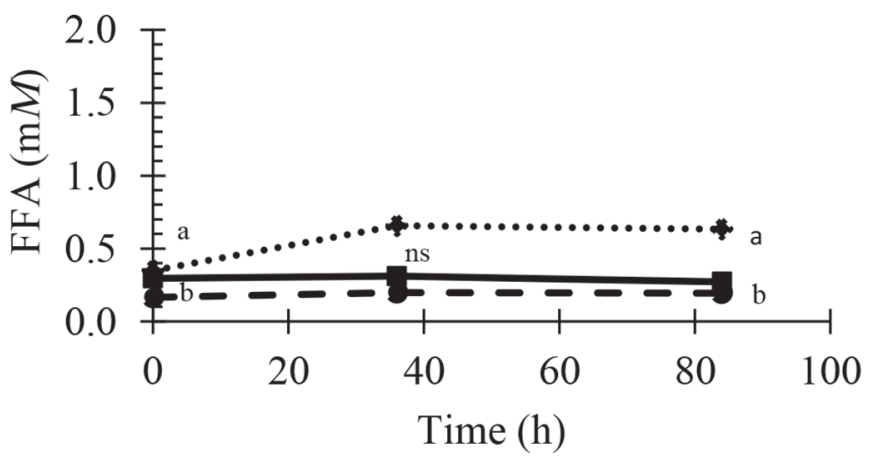

Figure 2. Milk lipolysis as shown by free fatty acid (FFA) content measured after 0,36 , and $84 \mathrm{~h}$ of storage in milk from goats receiving different lipid-supplemented concentrates [control feed with no extra fat $(-\mathbf{-}-)$; basal concentrate supplemented with hydrogenated palm oil enriched with palmitic acid $(\cdots \bullet \cdots)$; or basal concentrate supplemented with rapeseed oil $(--\bullet--)]$ from 90 to 230 DIM. Different letters indicate significant differences $(P<0.05)$ between the feeding groups. 
enriched with sunflower oil (rich in UFA; Eknæs et al., 2009). However, other studies have shown that supplementation with unsaturated fat may reduce LPL activity, content of FFA, and goaty flavor in milk (Skjevdal, 1979; Chilliard et al., 2003). Indeed, previous studies have shown a correlation between the content of FFA in milk and off-flavors (Deeth and Fitz-Gerald, 2006), and this is supported by the current experiment (Figures 3 and $4, \mathrm{r}=-0.84)$. The content of FFA obtained from the routine milk analysis (Milkoscan/FTIR) therefore gives a good indication of the sensory quality of the milk concerning off-flavors.

Liberation of short- and medium-chain fatty acids (C6:0-C10:0) is believed to be responsible for the specific goaty flavor (Brandsaeter and Abate, 1959), and perhaps also tart or rancid flavors (Deeth and FitzGerald, 2006). Branched-chain variants (methyl and ethyl) of caprylic acid are volatiles with very low flavor
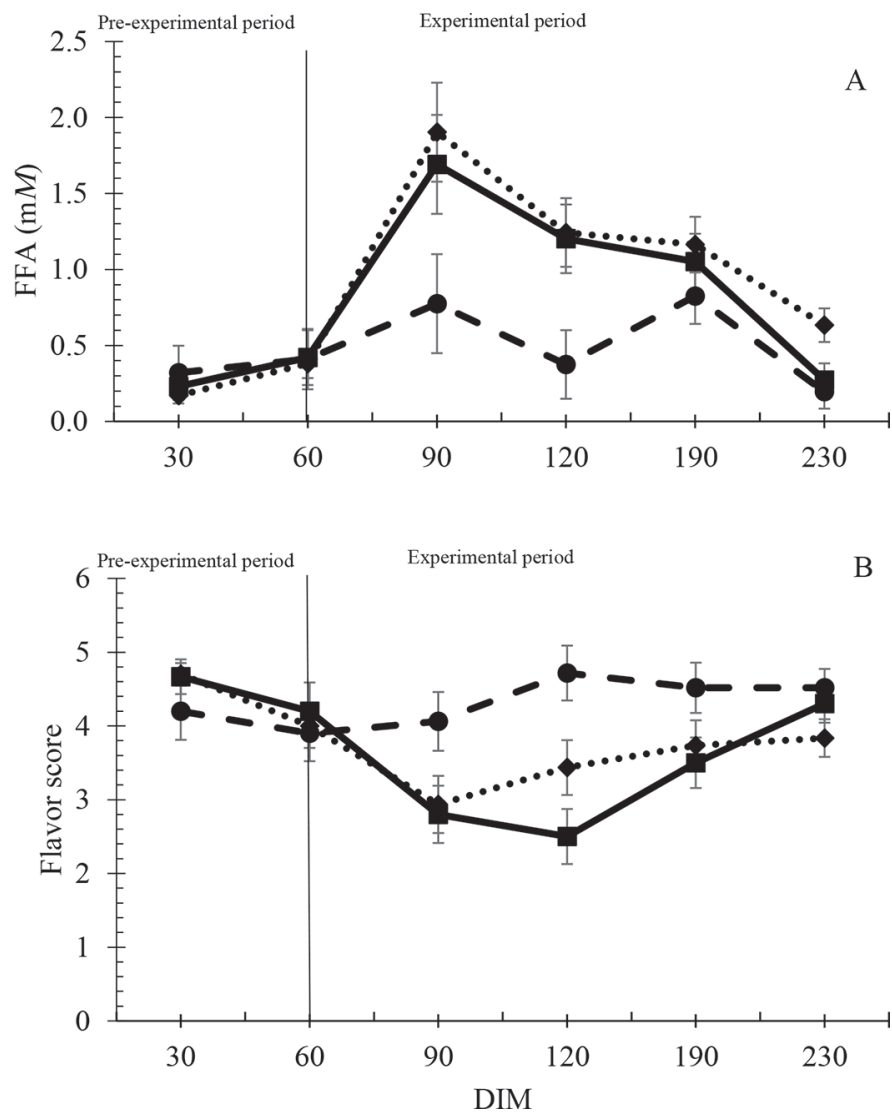

Figure 3. (A) Free fatty acid (FFA) content, and (B) milk flavor scores measured in milk stored for $84 \mathrm{~h}$. Samples were measured throughout a whole lactation from goats receiving different lipid-supplemented concentrates [control feed with no extra fat (- - ) ; basal concentrate supplemented with hydrogenated palm oil enriched with palmitic acid $(\cdots \uparrow \cdots)$; or basal concentrate supplemented with rapeseed oil (-- - $)$ ] from 61 to 230 DIM. The vertical line indicates start of the experimental period. Values at 30 and 60 DIM are means; values from 90 to 230 DIM are LSM. Error bars represent SEM. thresholds (Brennand et al., 1989), and are believed to be strong contributors to the flavors of goat milk (Chilliard et al., 2003). More than 20 of the FFA were analyzed to identify specific fatty acids responsible for the tart and rancid flavor; however, no branched-chain variants of caprylic acid were identified in our samples.

The fatty acid profiles of the FFA fraction appeared similar to the profiles of TG; however, the difference between samples in total content was much greater. Samples with a high content of FFA received low flavor scores and were characterized as tart or rancid (Figure 4). Those samples had a high content of all the identified fatty acids. Thus, we were not able to link any specific fatty acid(s) to either goaty flavor or to specific off-flavors (tart or rancid). The total number of FFA measured by FTIR from the routine analysis was a better indicator for off-flavors than the concentration of the individual FFA (Figure 4).

The FAME profiles of the FFA fraction in 2 samples with extremely high $(4.3 \mathrm{mM})$ and low $(0.1 \mathrm{mM})$ contents of FFA are shown in Figure 5. The sample with the extremely high content of FFA (A) contained peaks of both short- and long-chain fatty acids, whereas the profile of the sample with a low content of FFA contained only fatty acids originating from polypropylene contamination (details in Materials and Methods).

Some goats produced milk with a high $(>0.8 \mathrm{mM})$ concentration of FFA throughout the whole lactation period, whereas others had a high concentration only in mid lactation but acceptable levels at the start and end of lactation. Moreover, some goats consistently produced milk with a good flavor and low content of FFA. We know from previous studies that a genetic factor (of the CSN1S1 locus) is linked to high content of FFA in the milk of Norwegian dairy goats (Dagnachew et al., 2011; Dagnachew and Ådnøy, 2014); however, in our study, we observed that goats of genotypes other than E12-00 may also produce milk with a high content of FFA and off-flavors. Milk LPL activity and FFA content are reported to be higher in French goats of "weak" genotypes of CSN1S1 (Chilliard et al., 2003); however, no correlation was found in the present study between the LPL activity and content of FFA in milk $(\mathrm{r}=-0.187, \mathrm{n}=155)$ nor to the genotype of CSN1S1 (Table 6).

\section{Composition of Phospholipids and Cholesterol of the MFGM in Selected Samples}

As differences in LPL activity cannot explain the increased FFA content in some samples, we hypothesize that substrate availability may explain the differences in FFA content among the milk samples. The MFGM protects TG from lipolytic degradation, and the stabil- 

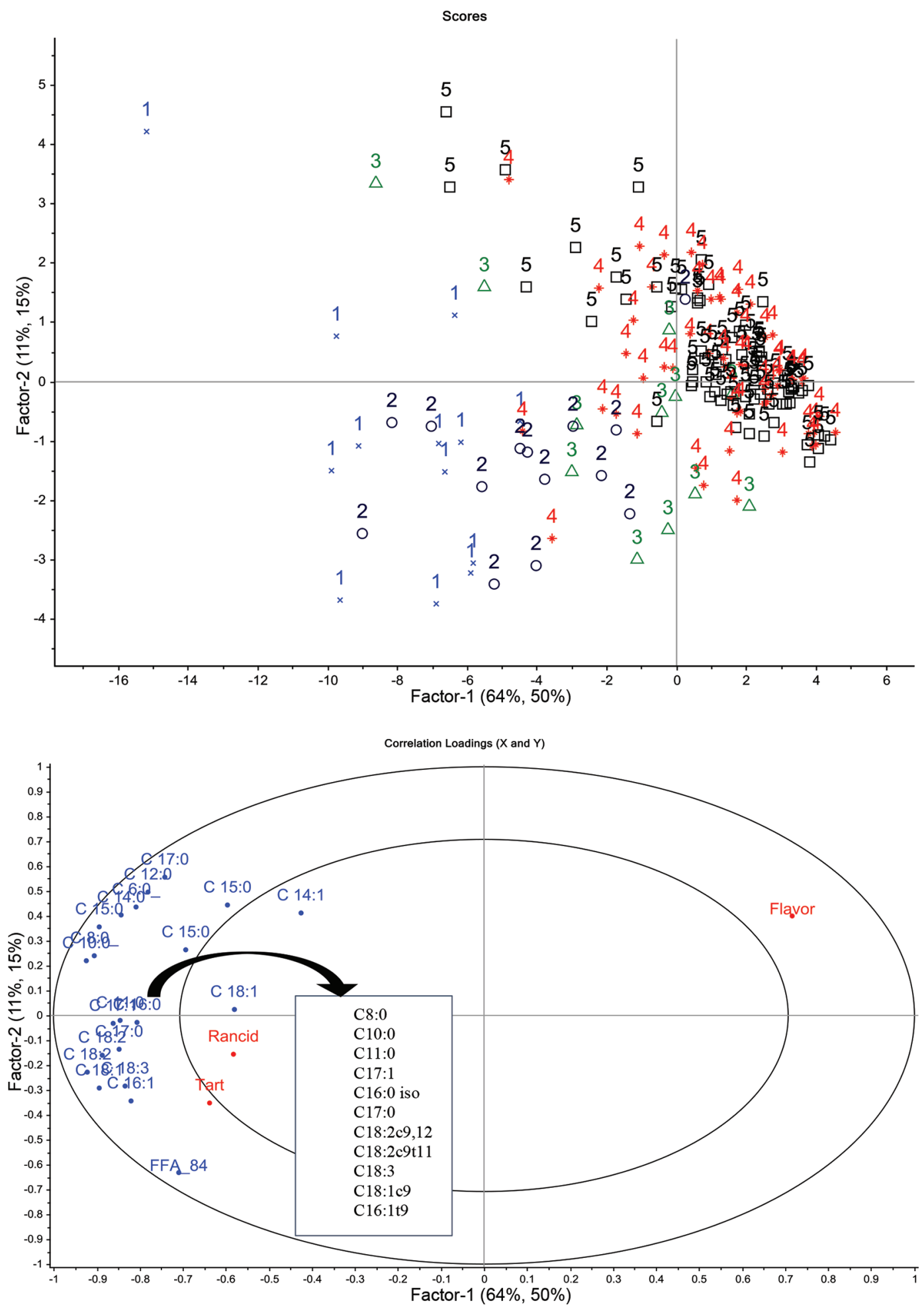

Figure 4. Partial least squares regression of free fatty acid (FFA) profile, total FFA, and flavor scores of all samples from 30 to 230 DIM. The score plot (top panel) shows the distribution of samples indicated by their flavor score [1-5, where 5 is best (no off-flavors) and 1 indicates high degree of off-flavors] and the corresponding loading plot (bottom panel) shows the distribution of variables (fatty acids, $\mathrm{c}=$ cis, $\mathrm{t}=$ trans; flavors). The first principal component (PC 1) explains 64 and $50 \%$ of the variation of the $\mathrm{x}$ and y variables, respectively, and PC 2 explains 11 and $15 \%$ of the variations in the $\mathrm{x}$ and $\mathrm{y}$ variables, respectively. Color version available online. 


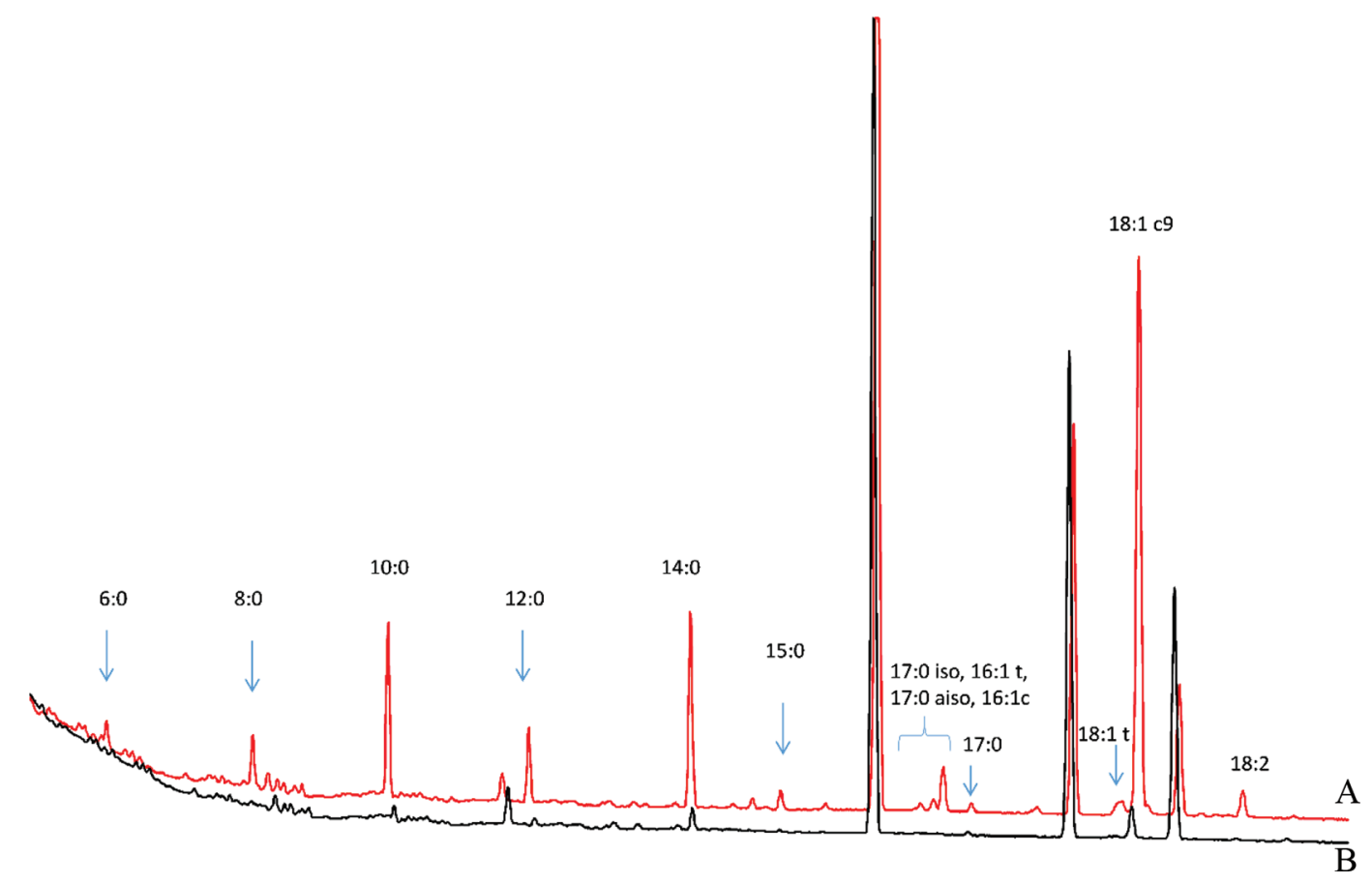

Figure 5. Comparison of 2 gas chromatograms of the fraction of free fatty acids (FFA) in goat milk: (A) extremely high (4.3 mM), and (B) low $(0.1 \mathrm{mM})$ total content of FFA; $\mathrm{c}=$ cis, $\mathrm{t}=$ trans, aiso $=$ anteiso. Color version available online.

ity of the MFGM may depend on its composition. We therefore examined possible differences in phospholipid and cholesterol composition of the MFGM to explain the different degree of lipolysis in the milk samples. Examination of the phospholipid composition and cholesterol content in 6 goat milk samples revealed differences between milk with a high content of FFA (2.9 \pm $1.25 \mathrm{mM})$ versus those with a low content of FFA (0.5 $\pm 0.17 \mathrm{mM}$; Figure 6). Samples with a high content of FFA had a higher content of cholesterol $(3.41 \pm 0.21$ $\mathrm{mg} / \mathrm{g}$ of fat) compared with those with low content of FFA $(2.72 \pm 1.79 \mathrm{mg} / \mathrm{g}$ of fat; $P=0.04)$. Cholesterol and sphingomyelin are the major constituents of lipid rafts in MFGM, which are the structures involved in different cellular processes, and cholesterol is reported to affect the MFGM organization (Murthy et al., 2015). A hydrolyzed variant of phosphatidylcholine, lysophosphatidylcholine (also called lysolecithin), was found in higher concentrations in samples with a high content of FFA ( 5.07 vs. $1.78 \mathrm{mg} / \mathrm{g}$ of fat); however, the difference was not statistically significant $(P=0.15)$. Lysophospholipids are known to have a strong affinity for both LPL and lipoproteins and may aid the LPL by disruption of the MFGM (Deeth and Fitz-Gerald, 1983). Sundheim et al. (1983) showed that exogenous lysophosphatidylcholine enhances cow milk lipolysis when activated by blood serum, but not in milk without serum addition.
The goat milk samples with a high degree of lipolysis also displayed a low content of phosphatidylethanolamine. Phosphatidylinositol and phosphatidylserine were not detected in any of the samples. The relationship between lipolysis and MFGM composition should be further investigated to unravel the mechanism of lipolysis in some milk samples.

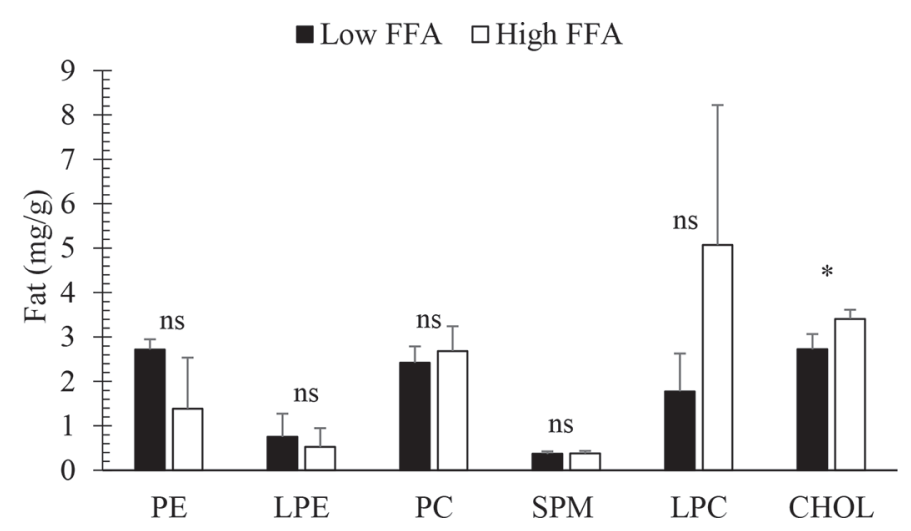

Figure 6. Content of polar lipids and cholesterol in milk from goats with high degree of lipolysis (white) and low degree of lipolysis (black). FFA = free fatty acids, $\mathrm{PE}=$ phosphatidyletanolamine, $\mathrm{LPE}$ $=$ lysophosphatidyletanolamine, $\mathrm{PC}=$ phosphatidylcholine, $\mathrm{SPM}=$ sphingomyelin, $\mathrm{LPC}=$ lysophosphatidylcholine, $\mathrm{CHOL}=$ cholesterol. Values are means $\pm \mathrm{SD} ; \mathrm{ns}=P>0.05,{ }^{*} P<0.05$.

Journal of Dairy Science Vol. 100 No. 9, 2017 


\section{CONCLUSIONS}

This study showed that it is possible to alter the milk fat content and composition of goat milk by altering the lipid composition of the concentrate fed. Feeding goats with a concentrate supplemented with rapeseed oil increased the content of most UFA and decreased the content of SFA in goat milk. In addition, rapeseed oil supplements resulted in lower LPL activity in the milk, lower content of FFA, and a higher flavor score compared with milk from goats receiving palm oil supplements or goats receiving a diet without fat supplements. Both types of oil increased the fat content in the milk, which correlates positively with the milk fat globule size. The presence of off-flavors and the total content of FFA in milk detected by the routine analysis (Milkoscan) were highly correlated. The positive effect of inclusion of rapeseed oil in the diet of goats has potential for development of new feeding strategies with feed based on sustainably produced lipid sources.

\section{ACKNOWLEDGMENTS}

The Norwegian Research Council (NFR, Lysaker, Norway ) and TINE BA (Oslo, Norway) financed this study. We thank the staff at the Animal Production Experimental Centre of NMBU for animal care and assistance with sampling procedures, Irene Comi (Department of Chemistry, Biotechnology and Food Sciences, NMBU, Norway) for technical assistance during milk sampling, Claes-Gøran Fristedt (Department of Animal and Aquacultural Sciences, NMBU, Norway) for measurements of the milk fat globule size, Kari Olsen (Department of Chemistry, Biotechnology and Food Sciences, NMBU, Norway) for assistance in the GC-FID analysis of the fatty acids, and Cyril Labonne (INRA, France) for assistance in LPL analysis. Harald Volden and Tormod Ådnøy (Department of Animal and Aquacultural Sciences, NMBU, Norway) are acknowledged for their advice regarding the experimental design and statistical analysis, respectively. We are very grateful for the sensory evaluation of the milk samples performed by Knut Erik Grindaker, Helga Kvamsås, and Kåre Johan Vassbotn (TINE). TINE provided Milkoscan analysis free of charge.

\section{REFERENCES}

Ahrné, L., and L. Björck. 1985. Lipolysis and the distribution of lipase activity in bovine milk in relation to stage of lactation and time of milking. J. Dairy Res. 52:55-64. https://doi.org/10.1017/ S002202990002389X.

Andrade, P., and P. Schmidely. 2006. Influence of percentage of concentrate in combination with rolled canola seeds on performance, rumen fermentation, and milk fatty acid composition in dairy goats. Livest. Sci. 104:77-90.
Attaie, R., and R. L. Richter. 2000. Size distribution of fat globules in goat milk. J. Dairy Sci. 83:940-944. https://doi.org/10.3168/jds. S0022-0302(00)74957-5.

Bauman, D. E., and J. M. Griinari. 2003. Nutritional regulation of milk fat synthesis. Annu. Rev. Nutr. 23:203-227.

Bernard, L., J. Rouel, C. Leroux, A. Ferlay, Y. Faulconnier, P. Legrand, and Y. Chilliard. 2005. Mammary lipid metabolism and milk fatty acid secretion in alpine goats fed vegetable lipids. J. Dairy Sci. 88:1478-1489. https://doi.org/10.3168/jds.S00220302(05)72816-2.

Brandsaeter, E., and V. Abate. 1959. Flavour compounds in goat's milk and goat whey cheese. 2. Occurrence of free fatty acids in goat whey cheese. Meldinger fra Norges Landbrukshogskole 38:1-12.

Brennand, C. P., J. K. Ha, and R. C. Lindsay. 1989. Aroma properties and thresholds of some branched-chain and other minor volatile fatty acids occurring in milkfat and meat lipids. J. Sens. Stud. 4:105-120. https://doi.org/10.1111/j.1745-459X.1989.tb00461.x.

Cebo, C., C. Lopez, C. Henry, C. Beauvallet, O. Ménard, C. Bevilacqua, F. Bouvier, H. Caillat, and P. Martin. 2012. Goat as1-casein genotype affects milk fat globule physicochemical properties and the composition of the milk fat globule membrane. J. Dairy Sci. 95:6215-6229. https://doi.org/10.3168/jds.2011-5233.

Chazal, M. P., and Y. Chilliard. 1986. Effect of stage of lactation, stage of pregnancy, milk yield and herd management on seasonal variation in spontaneous lipolysis in bovine milk. J. Dairy Res. $53: 529-538$.

Chilliard, Y., A. Ferlay, J. Rouel, and G. Lamberet. 2003. A review of nutritional and physiological factors affecting goat milk lipid synthesis and lipolysis. J. Dairy Sci. 86:1751-1770.

Chilliard, Y., F. Glasser, A. Ferlay, L. Bernard, J. Rouel, and M. Doreau. 2007. Diet, rumen biohydrogenation and nutritional quality of cow and goat milk fat. Eur. J. Lipid Sci. Technol. 109:828855. https://doi.org/10.1002/ejlt.200700080.

Coppa, M., A. Ferlay, F. Monsallier, I. Verdier-Metz, P. Pradel, R. Didienne, A. Farruggia, M. C. Montel, and B. Martin. 2011. Milk fatty acid composition and cheese texture and appearance from cows fed hay or different grazing systems on upland pastures. J. Dairy Sci. 94:1132-1145. https://doi.org/10.3168/jds.2010-3510.

Couvreur, S., C. Hurtaud, C. Lopez, L. Delaby, and J. L. Peyraud. 2006. The linear relationship between the proportion of fresh grass in the cow diet, milk fatty acid composition, and butter properties. J. Dairy Sci. 89:1956-1969. https://doi.org/10.3168/jds. S0022-0302(06)72263-9.

Dagnachew, B. S., and T. Ådnøy. 2014. Additive and dominance effects of casein haplotypes on milk composition and quality in Norwegian dairy goats. Small Rumin. Res. 122:59-69. https://doi. org/10.1016/j.smallrumres.2014.07.020.

Dagnachew, B. S., G. Thaller, S. Lien, and T. Adnoy. 2011. Casein SNP in Norwegian goats: additive and dominance effects on milk composition and quality. Genet. Sel. Evol. 43:31.

Deeth, H., and C. Fitz-Gerald. 1983. Lipolytic enzymes and hydrolytic rancidity in milk and milk products. Pages 195-239 in Developments in Dairy Chemistry - 2. Springer, New York, NY.

Deeth, H. C. 2006. Lipoprotein lipase and lipolysis in milk. Int. Dairy J. 16:555-562.

Deeth, H. C., and C. H. Fitz-Gerald. 2006. Lipolytic enzymes and hydrolytic rancidity. Pages 481-556 in Advanced Dairy Chemistry. Vol. 2: Lipids. P. F. Fox and P. L. H. McSweeney, ed. Springer, New York, NY.

Devle, H., E. K. Ulleberg, C. F. Naess-Andresen, E.-O. Rukke, G. Vegarud, and D. Ekeberg. 2014. Reciprocal interacting effects of proteins and lipids during ex vivo digestion of bovine milk. Int. Dairy J. 36:6-13. https://doi.org/10.1016/j.idairyj.2013.11.008.

Dønnem, I., Å. T. Randby, and M. Eknæs. 2011. Effect of grass silage harvesting time and level of concentrate supplementation on goat milk quality. Anim. Feed Sci. Technol. 163:118-129. https://doi. org/10.1016/j.anifeedsci.2010.10.013.

Eknæs, M., Y. Chilliard, K. Hove, R. A. Inglingstad, L. Bernard, and H. Volden. 2017. Effects of feeding palm oil fatty acids or rapeseed oil throughout lactation on energy status, body composi- 
tion and milk production in Norwegian dairy goats. J. Dairy Sci. 100:7588-7601. https://doi.org/10.3168/jds.2017-12768.

Eknæs, M., K. Kolstad, H. Volden, and K. Hove. 2006. Changes in body reserves and milk quality throughout lactation in dairy goats. Small Rumin. Res. 63:1-11.

Eknæs, M., Ø. Havrevoll, H. Volden, and K. Hove. 2009. Fat content, fatty acid profile and off-flavours in goats milk-Effects of feed concentrates with different fat sources during the grazing season. Anim. Feed Sci. Technol. 152:112-122. https://doi.org/10.1016/j. anifeedsci.2009.04.006.

FAO. 2010. Fats and fatty acids in human nutrition. Report of an expert consultation. Food and Agriculture Organization of the United Nations (FAO), Rome, Italy.

Folch, J., M. Lees, and G. H. Sloane Stanley. 1957. A simple method for the isolation and purification of total lipids from animal tissue. J. Biol. Chem. 226:497-509.

Granlund, L. L., R. Eltun, E. E. Hohle, L. Nesheim, W. Waalen, and M. Åssveen. 2010. Biodiesel fra norske jordbruksvekster, Utredning for prosjekt ["Opportunities for Norwegian production of biodiesel from agricultural crops"] (Bioforsk, Trans.) Vol. 5. www. bioforsk.no.

Gulati, S. K., E. B. Byers, Y. G. Byers, J. R. Ashes, and T. W. Scott. 1997. Effect of feeding different fat supplements on the fatty acid composition of goat milk. Anim. Feed Sci. Technol. 66:159-164. https://doi.org/10.1016/S0377-8401(96)01117-0.

Hayes, K. C., P. Khosla, T. Hajri, and A. Pronczuk. 1997. Saturated fatty acids and LDL receptor modulation in humans and monkeys. Prostaglandins Leukot. Essent. Fatty Acids 57:411-418.

Inglingstad, R. A., M. Eknæs, L. Brunborg, T. Mestawet, T. G. Devold, G. E. Vegarud, and S. B. Skeie. 2016. Norwegian goat milk composition and cheese quality: The influence of lipid supplemented concentrate and lactation stage. Int. Dairy J. 56:13-21. https:// doi.org/10.1016/j.idairyj.2015.12.010.

Khorasani, G. R., E. K. Okine, and J. J. Kennelly. 1996. Forage source alters nutrient supply to the intestine without influencing milk yield. J. Dairy Sci. 79:862-872. https://doi.org/10.3168/jds.S00220302(96)76435-4.

Littell, R. C., P. R. Henry, and C. B. Ammerman. 1998. Statistical analysis of repeated measures data using SAS procedures. J. Anim. Sci. 76:1216-1231.

Lopez, C., V. Briard-Bion, O. Menard, F. Rousseau, P. Pradel, and J.-M. Besle. 2008. Phospholipid, sphingolipid, and fatty acid compositions of the milk fat globule membrane are modified by diet. J. Agric. Food Chem. 56:5226-5236. https://doi.org/10.1021/ jf7036104.

Ménard, O., S. Ahmad, F. Rousseau, V. Briard-Bion, F. Gaucheron, and C. Lopez. 2010. Buffalo vs. cow milk fat globules: Size distribution, zeta-potential, compositions in total fatty acids and in polar lipids from the milk fat globule membrane. Food Chem. 120:544-551. https://doi.org/10.1016/j.foodchem.2009.10.053.

Michalski, M.-C., V. Briard, and F. Michel. 2001. Optical parameters of milk fat globules for laser light scattering measurements. Lait 81:787-796.

Mir, Z., L. A. Goonewardene, E. Okine, S. Jaegar, and H. D. Scheer. 1999. Effect of feeding canola oil on constituents, conjugated linoleic acid (CLA) and long chain fatty acids in goats milk. Small Rumin. Res. 33:137-143. https://doi.org/10.1016/S09214488(99)00016-4.

Murthy, A. V. R., F. Guyomarc'h, G. Paboeuf, V. Vié, and C. Lopez. 2015. Cholesterol strongly affects the organization of lipid monolayers studied as models of the milk fat globule membrane: Condensing effect and change in the lipid domain morphology. Bio- chim. Biophys. Acta 1848:2308-2316. https://doi.org/10.1016/j. bbamem.2015.06.014.

Ollier, S., C. Leroux, A. de la Foye, L. Bernard, J. Rouel, and Y. Chilliard. 2009. Whole intact rapeseeds or sunflower oil in highforage or high-concentrate diets affects milk yield, milk composition, and mammary gene expression profile in goats. J. Dairy Sci. 92:5544-5560. https://doi.org/10.3168/jds.2009-2022.

Onetti, S. G., and R. R. Grummer. 2004. Response of lactating cows to three supplemental fat sources as affected by forage in the diet and stage of lactation: A meta-analysis of literature. Anim. Feed Sci. Technol. 115:65-82. https://doi.org/10.1016/j. anifeedsci.2004.02.009.

Palmquist, D. L. 1984. Calcium soaps of fatty acids with varying unsaturation as fat supplements for lactation cows. Can. J. Anim. Sci. 64:240-241. https://doi.org/10.4141/cjas84-242.

Pisanu, S., G. Marogna, D. Pagnozzi, M. Piccinini, G. Leo, A. Tanca, A. M. Roggio, T. Roggio, S. Uzzau, and M. F. Addis. 2013. Characterization of size and composition of milk fat globules from Sarda and Saanen dairy goats. Small Rumin. Res. 109:141-151. https://doi.org/10.1016/j.smallrumres.2012.07.024.

Rabiee, A. R., K. Breinhild, W. Scott, H. M. Golder, E. Block, and I. J. Lean. 2012. Effect of fat additions to diets of dairy cattle on milk production and components: A meta-analysis and metaregression. J. Dairy Sci. 95:3225-3247. https://doi.org/10.3168/ jds.2011-4895.

Sanz Sampelayo, M. R., Y. Chilliard, P. Schmidely, and J. Boza. 2007. Influence of type of diet on the fat constituents of goat and sheep milk. Small Rumin. Res. 68:42-63. https://doi.org/10.1016/j. smallrumres.2006.09.017.

Shingfield, K. J., Y. Chilliard, V. Toivonen, P. Kairenius, and D. I. Givens. 2008. Trans fatty acids and bioactive lipids in ruminant milk. Pages 3-65 in Bioactive Components of Milk. Vol. 606. Z. Bösze, ed. Springer, New York, NY.

Skjevdal, T. 1979. Flavour of goat's milk: A review of studies on the sources of its variations. Livest. Prod. Sci. 6:397-405.

Steinshamn, H., R. A. Inglingstad, D. Ekeberg, J. Mølmann, and M. Jørgensen. 2014. Effect of forage type and season on Norwegian dairy goat milk production and quality. Small Rumin. Res. 122:18 30. https://doi.org/10.1016/j.smallrumres.2014.07.013.

Sundheim, G., T.-L. Zimmer, and H. Astrup. 1983. Induction of milk lipolysis by lipoprotein components of bovine blood serum. J. Dairy Sci. 66:400-406.

R Core Team. 2016. R: A language and environment for statistical computing. R Foundation for Statistical Computing, Vienna, Austria. www.R-project.org.

Tudisco, R., B. Chiofalo, L. Addi, V. L. Presti, R. Rao, S. Calabro', N. Musco, M. Grossi, M. I. Cutrignelli, V. Mastellone, P. Lombardi, and F. Infascelli. 2015. Effect of hydrogenated palm oil dietary supplementation on milk yield and composition, fatty acids profile and stearoyl-CoA desaturase expression in goat milk. Small Rumin. Res. 132:72-78. https://doi.org/10.1016/j. smallrumres.2015.10.006.

Wiking, L., J. Stagsted, L. Bjorck, and J. H. Nielsen. 2004. Milk fat globule size is affected by fat production in dairy cows. Int. Dairy J. 14:909-913.

Wilcove, D. S., X. Giam, D. P. Edwards, B. Fisher, and L. P. Koh. 2013. Navjot's nightmare revisited: Logging, agriculture, and biodiversity in Southeast Asia. Trends Ecol. Evol. 28:531-540. https://doi.org/10.1016/j.tree.2013.04.005.

Wolfinger, R. D. 1996. Heterogeneous variance: Covariance structures for repeated measures. J. Agric. Biol. Environ. Stat. 1:205-230. 